\title{
علاقة أساليب المعاهلة الوالدية \\ باتخاذ الأبناء لقراراتهم في المرحلة الثانوية
}

\author{
إعداد \\ أ. إنعام أحمد عابد شعيبحس. \\ المعيدة بقسم السكن وإدارة المنزل \\ كلية الفنون والتصميم الداخلي _ جـامعة أم القرى
}

مجلة بحوث التربية النوعية - جامعة المنصورة

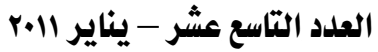




\title{
علاقة أساليب المعاهلة الوالدية باتخاذ الأبناء لقراراتهم في المرحلة الثانوية
}

\author{
إعداد \\ إنعام أحمد عابد شعيبيـ
}

\section{هذص البحث}

تهـدف هـذه الدراسـة إلى الكشف عـن العلاقـة بـين أسـاليب المعاملـة الوالديـة، واتخـاذ الأبنـاء

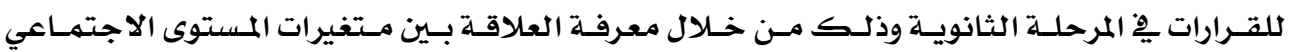

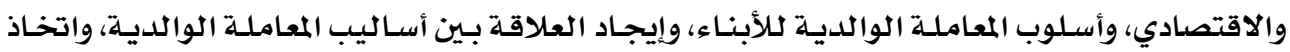

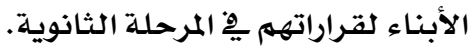

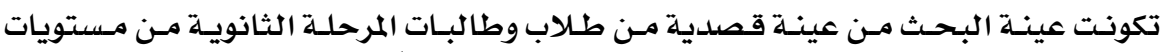

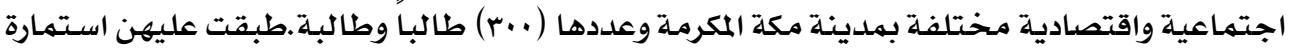

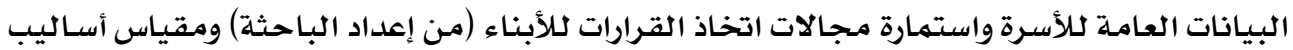

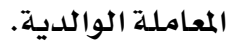

وأسفرت نتائج الدراسـة عن وجـود فروق ذات دلالـة إحصائية عند مستوى ه •. • بـين الذكور

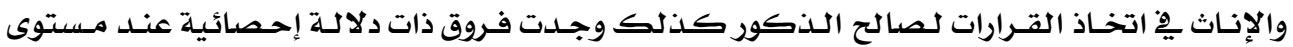

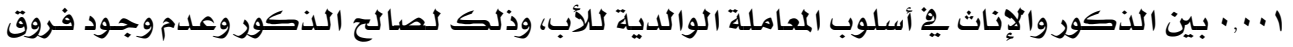

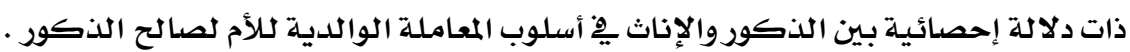

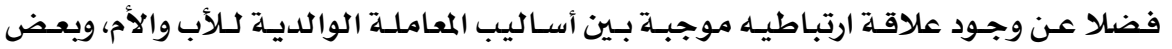

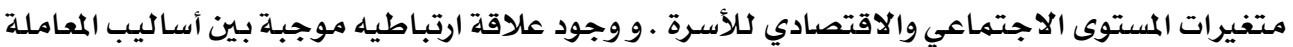

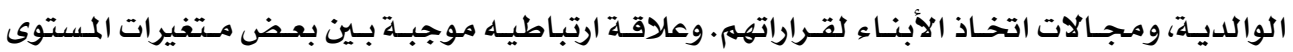

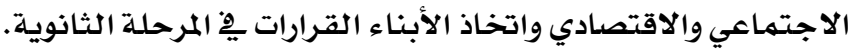

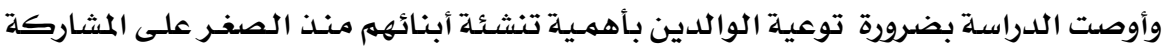

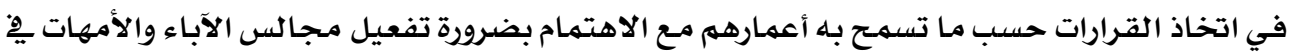

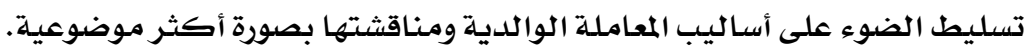




\section{RELATIONSHIP OF PARENTAL TREATMENT STYLES AND GHILDREN TO TAKE DECISIONS IN THE SECONDARY STAGE}

Enaam Ahmed Abed Shuaibi

\section{Abstract}

The object of this study was to discover the relation between " parental treatment methods and the children's decisions-making at the secondary schools phase. That's through knowing the relation between the variables of social and economical levels and methods of parental treatment , to find out the relation between " parental treatment methods and the children's decisions-making at the secondary schools stage . a meant sample has been chosen from secondary schools' students(male and female) from different social and economical levels about(300) single. Also a questionnaire has been used to measure the relation between" parental treatment methods and the children's decisions-making. The research tools which were used were determined in a questionnaire for family general data, the fields of children's decisions-making, and parental treatment methods . also a special Statistical treatment has been done to analyze the questionnaire data in order to get the final results. The most important finding were:

1. There are statistically significant differences between males and females in decision-making in favor of males.

2. There are no statistically significant differences between males and females in the way of parental treatment for the mother.

3. There is a positive correlated relationship between the methods of Parental treatment to the father and mother and some social and economic levels variables.

4. There is a positive correlated relationship between parental treatment methods and the total of children's decisions making fields.

According to the research findings, the researcher provides some recommendations and suggestions:

To organize magazines to increase awareness via different audio able, visual and readable information media programs which aimed to raise public awareness of parents with the corrected educational methods in the upbringing of children 


\title{
علاقة أساليب المعاهلة الوالدية باتخاذ الأبناء لقراراتهم في المرحلة الثانوية
}

\author{
إعداد \\ إنعام أحمد عابد شعيبيـ
}

\section{هقدمة ومشكلة البحث:}

تعتبر إدارة المنزل أحد مجالات الدراسـة لعلم الاقتصـاد المنزلي بل هي ِِّ الواقع تمثل العمـود

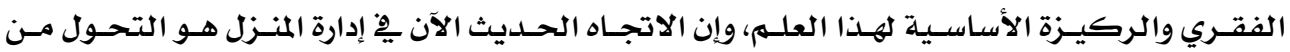

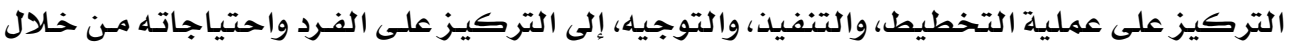

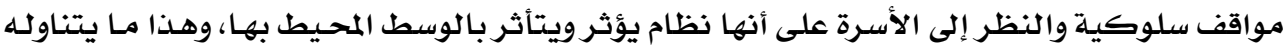

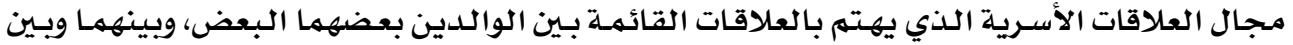

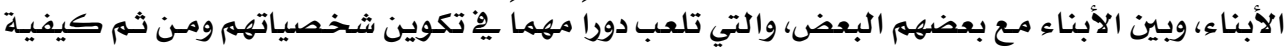

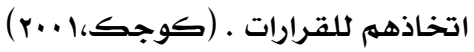

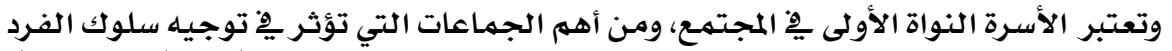

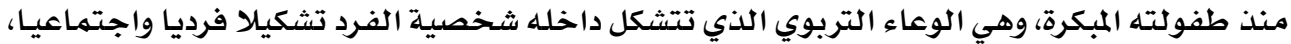

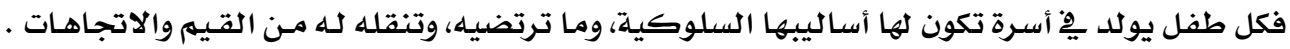

(شلبب، (1999)

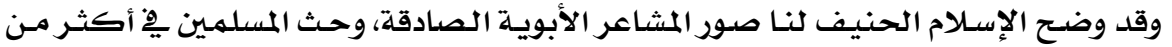

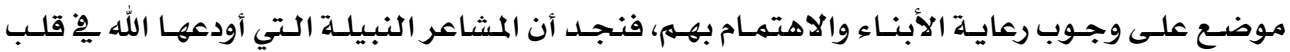

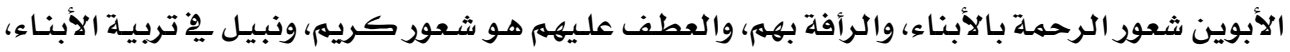

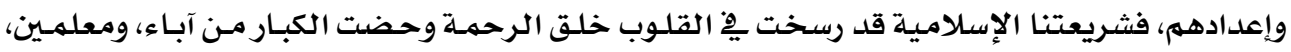

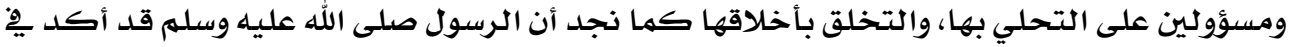

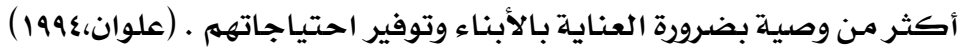
وقد أثـاد العديـد مـن البـاحثين أن مـرحلـة المراهقة الوسطى (10- ـاسنـة) مـن أهـم مـراحل

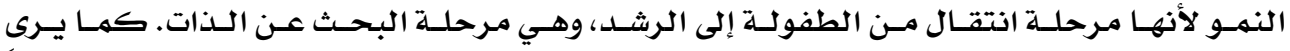

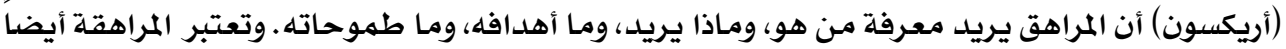

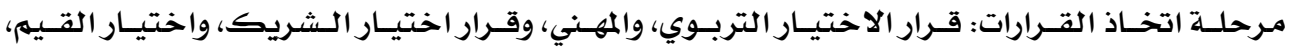

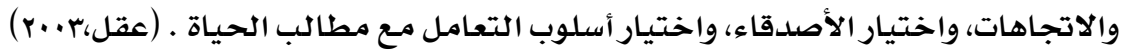

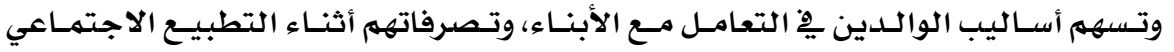

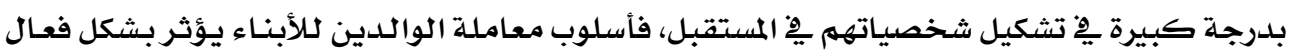




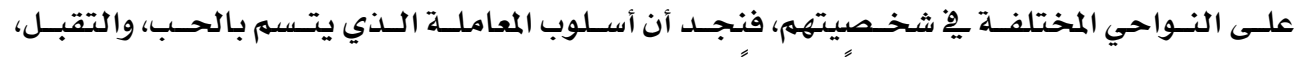

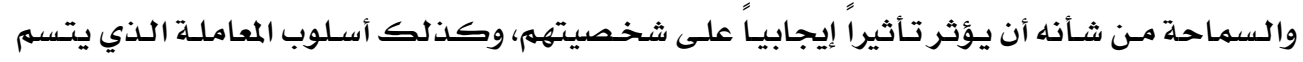

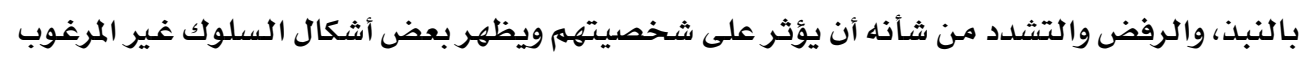

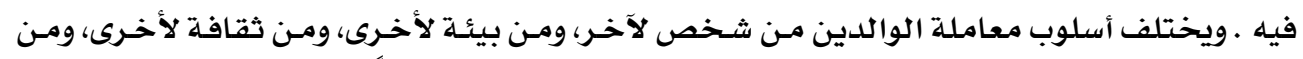

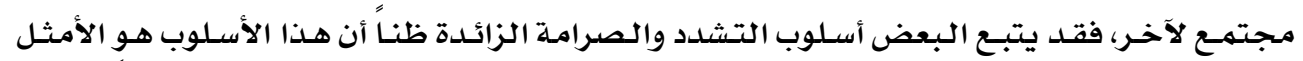

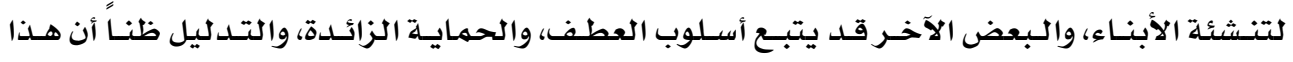

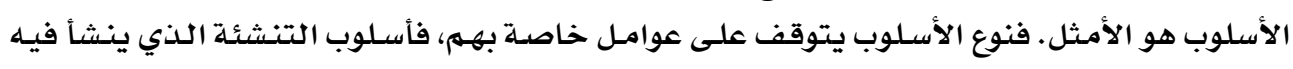

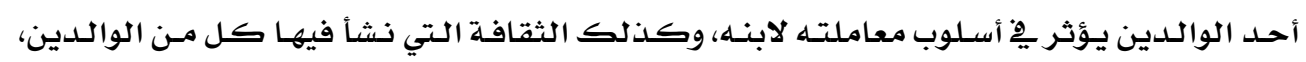

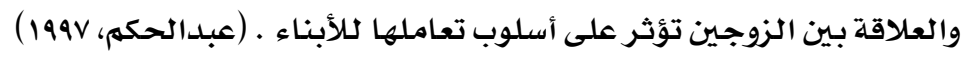

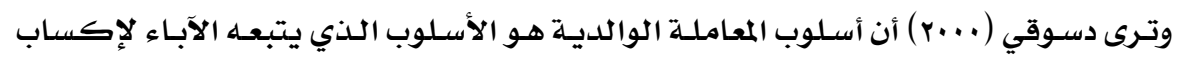

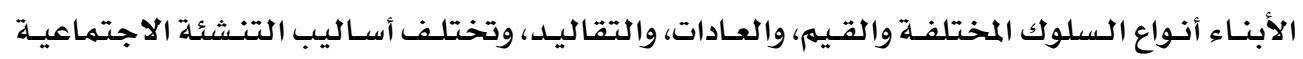

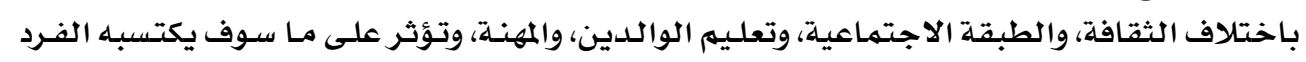

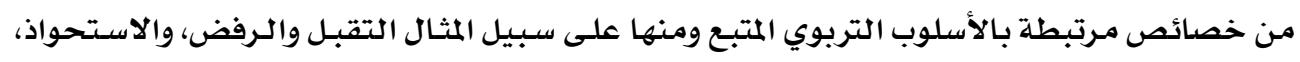
والضبط، والإكراه، والفردية

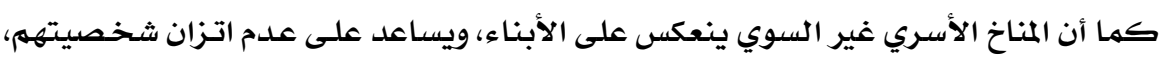

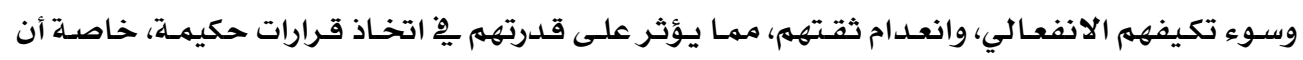

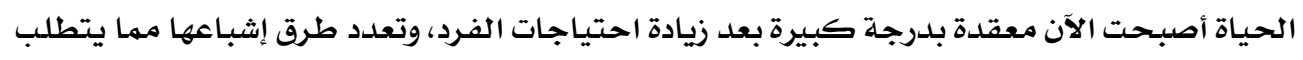

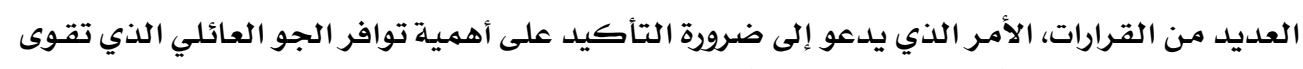

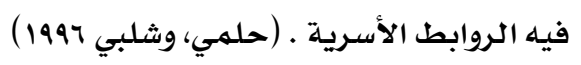

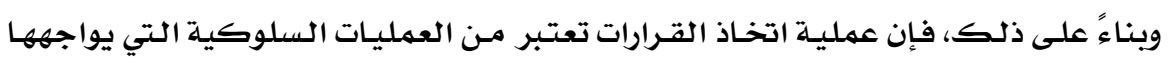

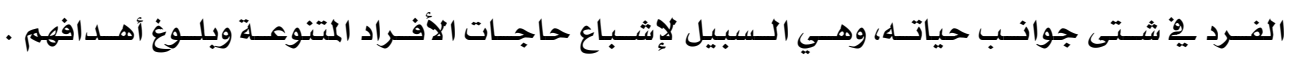

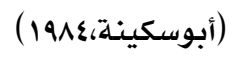

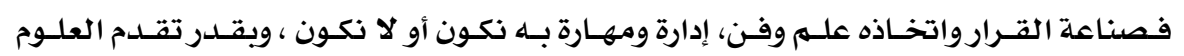

والتكنولوجيا تزداد أهميلة وجوده، وسير اتخاذه ـ (حسيب، (1997)

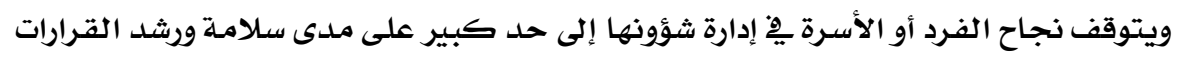

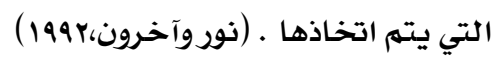

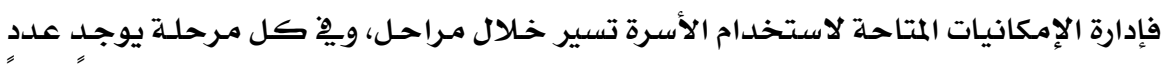

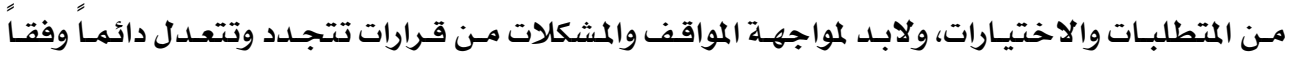

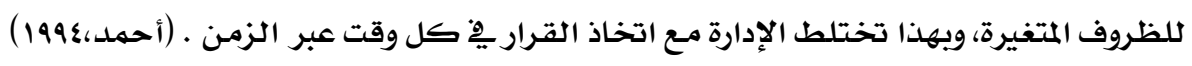

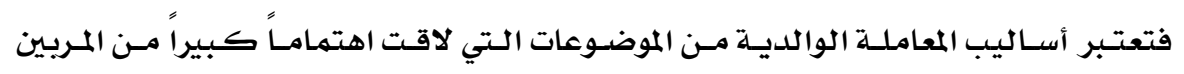

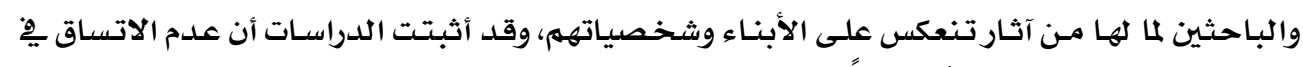

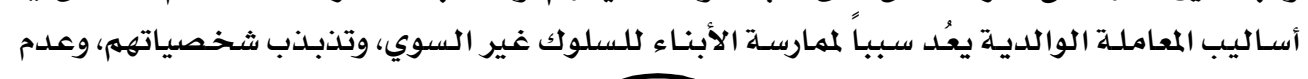




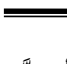

مجلة بحوث التربية النوعية - العلد التاسع عشر - ينايرا

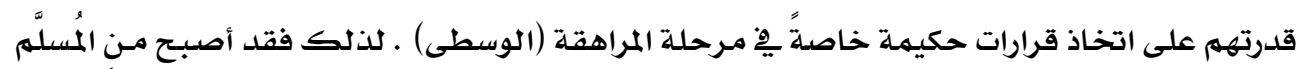

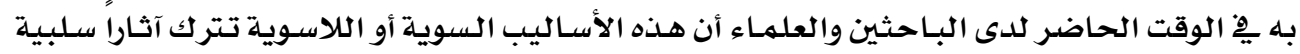

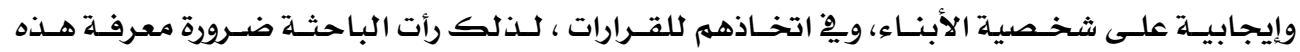

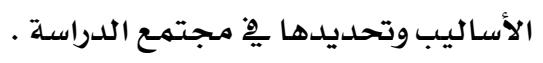

وعلى ضوء مـا سبق تتبلور مشكلة البـحث يِ التساؤلات التالية :

1- ما الفروق بين الأبناء (ذكور وإناث) يِ القدرة على اتخاذ القرارات؟

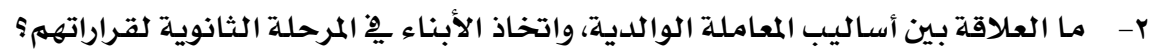

ب- مـ ما الفروق بين الأبناء (ذكور وإناث) مِ أسـاليب المعاملة الوالدية (الأب والأم)؟ ع- مـا مدى تأثير اختاف المستوى الاجتهماعي والاقتصادي لكلأسرة على أسـاليب المعاملة الوالدية

لأبنائهم

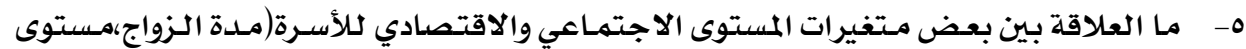

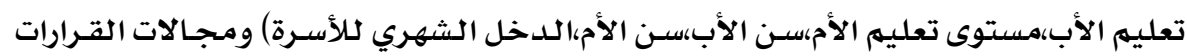

التي يتخذها الأبناء يِّ المرحلة الثانويـة ؟

أهد|ف البحث :

يهدف البححث إلى التعرف على :

1 - الفروق بين الأبناء( ذكور وإناث) يِّ القدرة على اتخاذ القرارات.

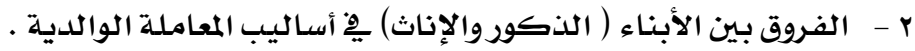

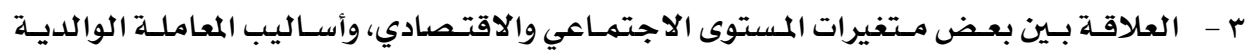

لـلأبناء (الأسلوب العقابي،أسلوب سـحب الحب، الأسلوب الإرثـادي التوجيهي)

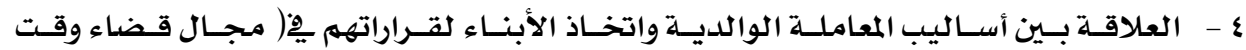

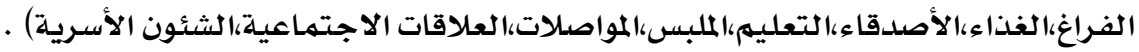

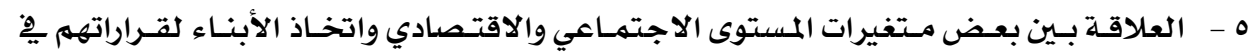

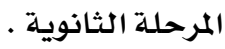

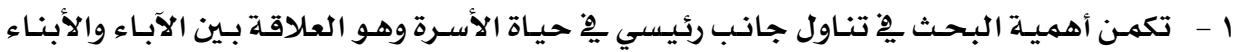

وهو أسلوب المعاملة الوالدية الذي ينعكس بلدوره على شخصيات الأبناء وسلوكهم .

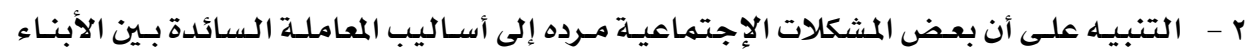

وآبائهم ولا يهكن حل هذه المشكلات إلا بتعديل أساليب المعامللة .

ץ - التركيـز على فئسة الشبـاب (10- 11) )لأنهـم عمـاد الأمسة ومسستقبلها وتـذليل العقبـات الـتي

تحول دون إكسـابهم السـلوك الإداري السليم وخاصسة القدرة على اتخاذ القرار •

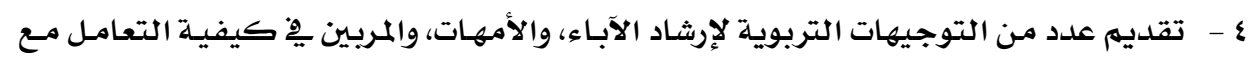

الأبناء يِّ هذه المرحلة. 
1 - توجد فروق ذات دلالة إحصائية بين استجابات الأبناء تبعا لاختلاف النوع ( الذكور والإناث )

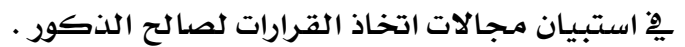

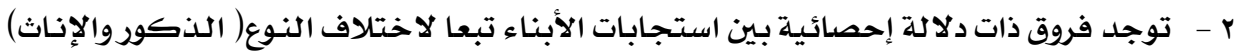

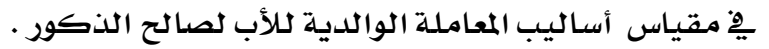

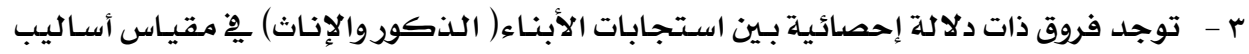

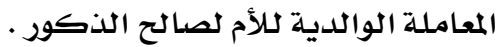

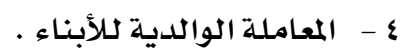

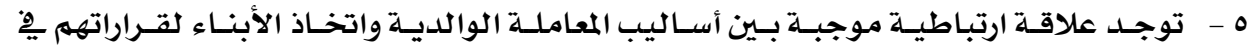

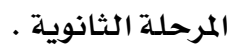

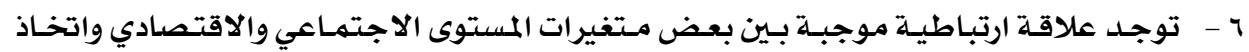

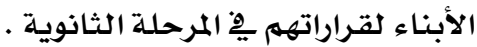

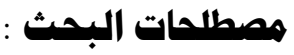 \\ أولاً : المصطلحات العلمية :}

Parent Treatment Styles : - أساليب المعاملة الوالدية المهية

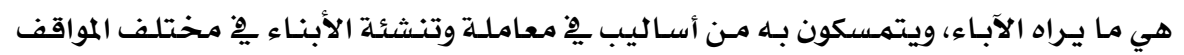

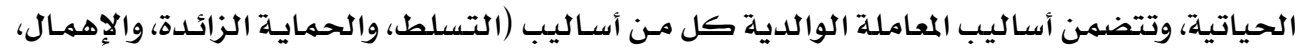

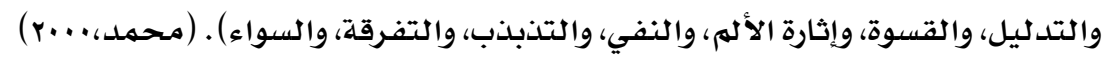
كهـا يعـرف بودسيكا Poduska أسـاليب المعاملـة الوالديـة بأنها شعور الأبنـاء إزاء معاملـة

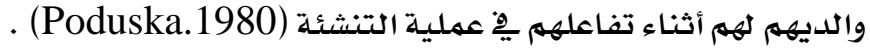

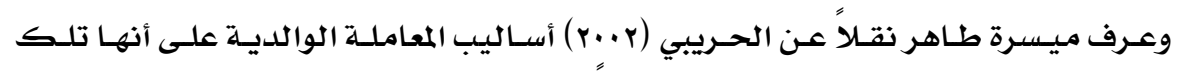

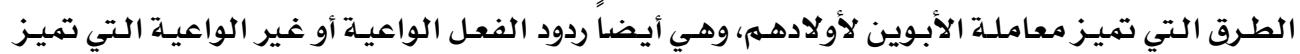

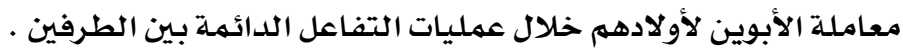
ثم تعرف الباحثة أساليب المعاملة الوالدية إجرائيا بأنها طرق وإجراءات يتبعها الوالدين يِّين

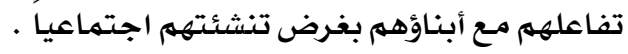
Decision : r القرار هـي كلمسة إنجليزيـة مسشتقة مـن الأصـل النلاتـيني Deceturn ويقـصلد بهـا البـت النهـائي

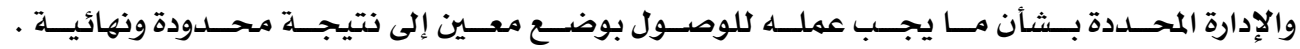
(عبدالنبي،1994) 


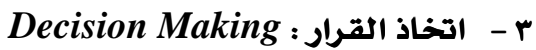

هي مجرد الاختيار المقترح الذي يتضـح من الخبر ات السابقة، ويستقر رأي المقرر على أفضل

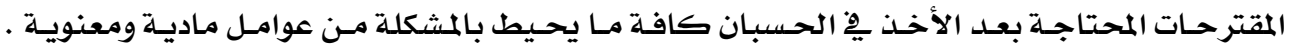

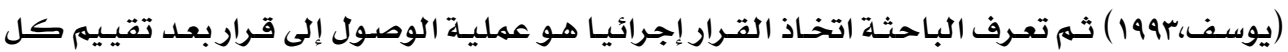

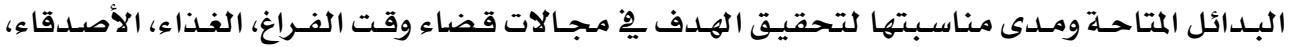

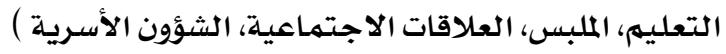

Adolescence : ع المراهقة

تعرف المراهقة بأنها مـرحلة من مـراحل العمر التي ينتقل فيها الفرد من مرحلة الطفولة إلى

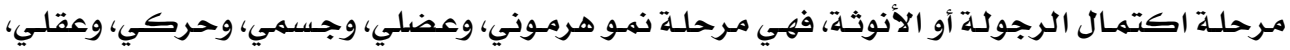

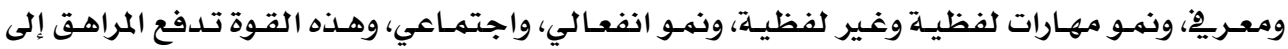

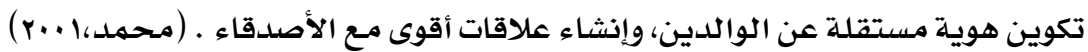

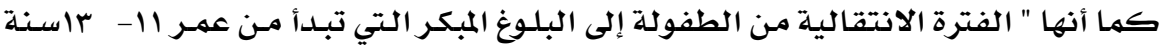

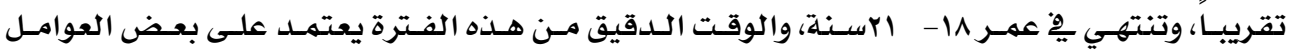

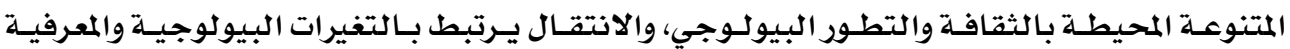

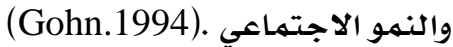
ثم تعرف الباحثة المراهقة إجرائيا هي مرحلة من العمـر تتوسط الطفولة، واكتمال النضجج،

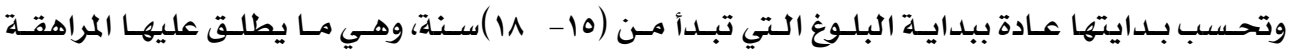

\section{الأسلوب البمثي للدوراسة: ا}

يتبع هذا البـحث المنهج الوصفي التحليلي، الذي يعتمـد على دراسـة الوقائع ويهتهم بوصفها

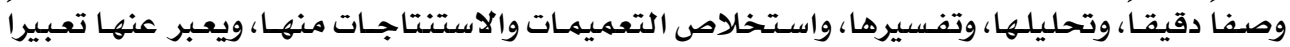

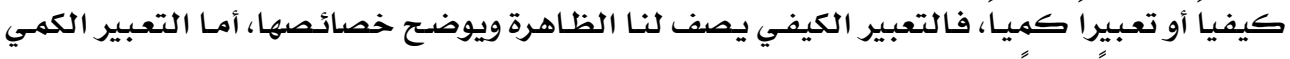

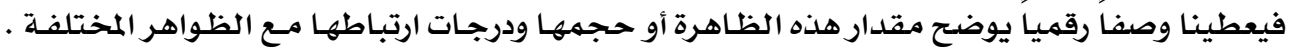

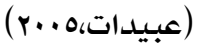

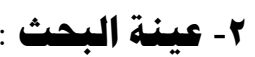

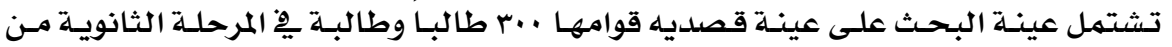

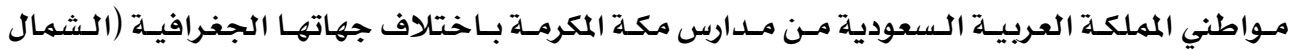

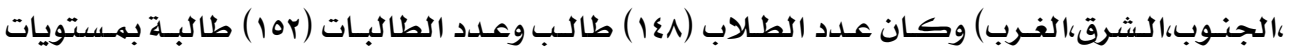

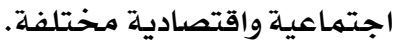




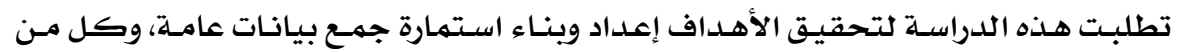

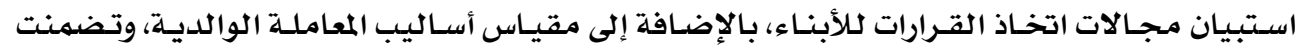

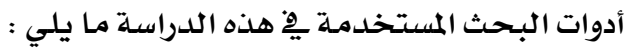

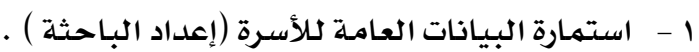
r - استبيان مجالات اتخاذ القرارات للأبناء (إعداد الباحثة ) . ل

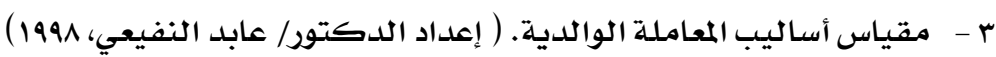

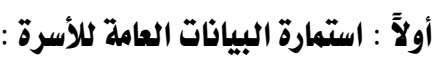

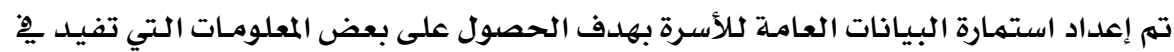

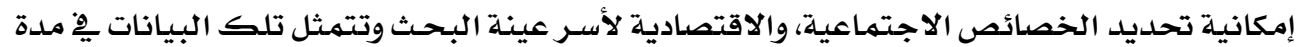

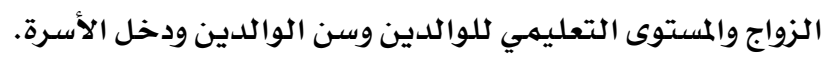

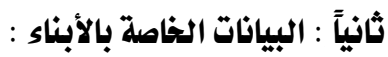

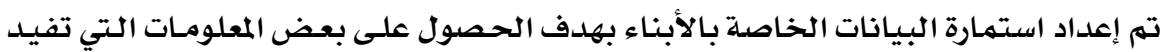

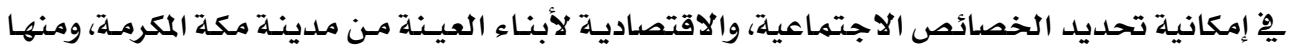

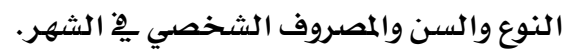
ثالثاً : استبيان مجالات اتخاذ القرارات للأبناء :

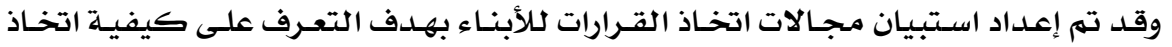

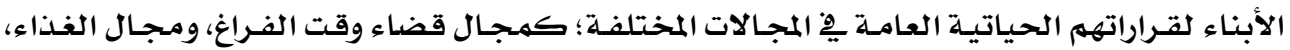

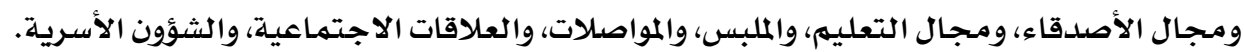

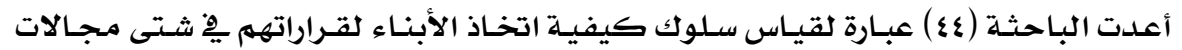
الحياة المختلفة . وقد تم توزيعها على ثمانية محاور وهي : المحور الأول : مجال قضاء وقت الفراغ :

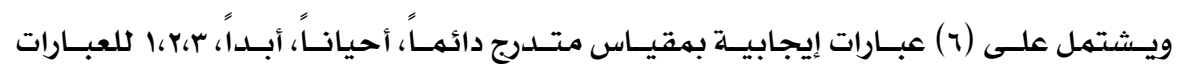

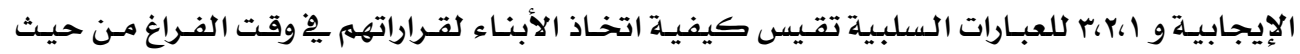

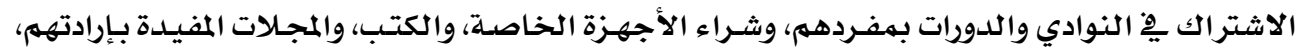

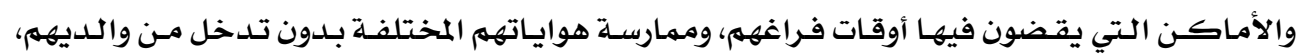

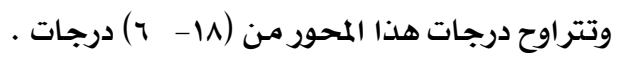


المحور الثاني : مجال الغذاء :

ويشتمل على (ع) ايجابية عبارات تقيس كيفية اتخاذ القرارات من الناحية الغذائية للأبناء

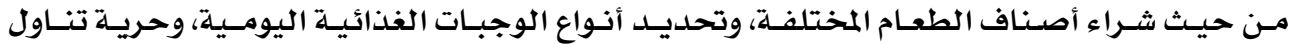

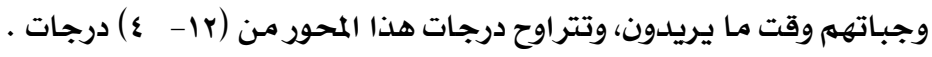

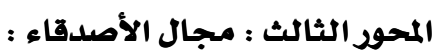

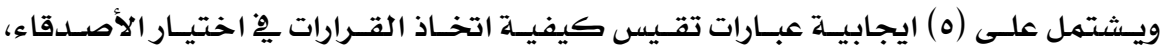

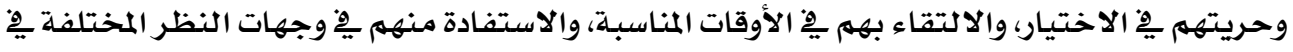

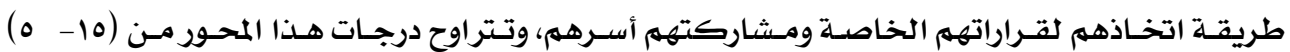

\section{المحور الرابع : مجال التعليم :}

ويشتمل على (^) ايجابيـة عبـارات تقيس كيفيـة اتخـاذ القرارات لمجال التعليهم للأبنـاء مـن

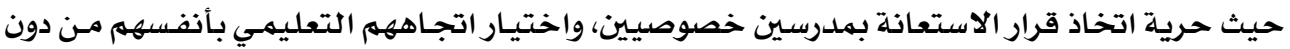

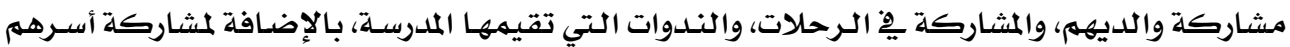

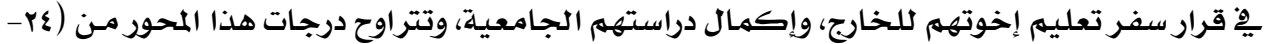
^) درجات . المحور الخامس : مجال الملبس :

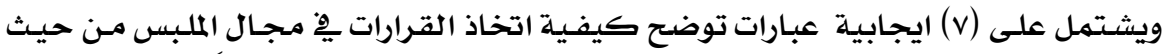

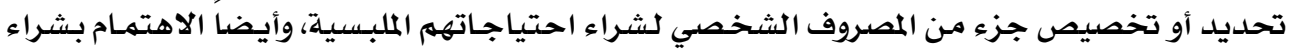

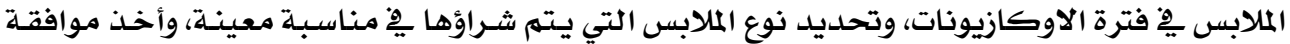

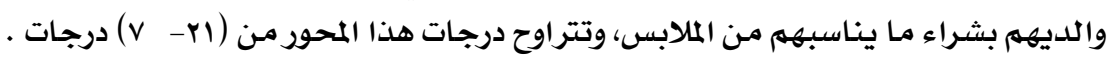
المحور السادس : مجال المواصلات :

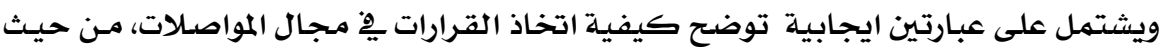

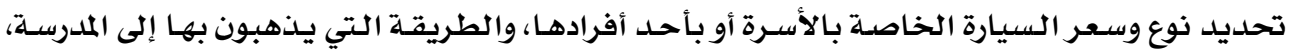

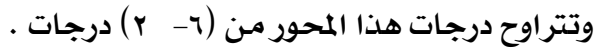
المحور السابع : مجال العلاقات الاجتماعية :

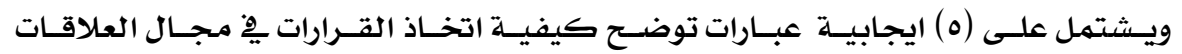

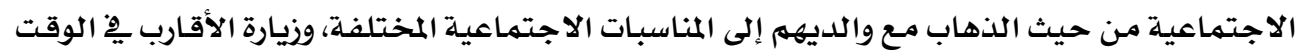

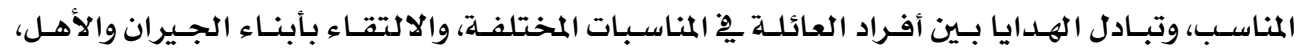

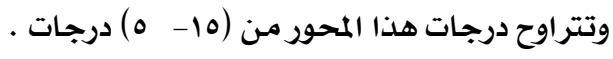




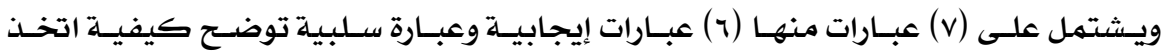

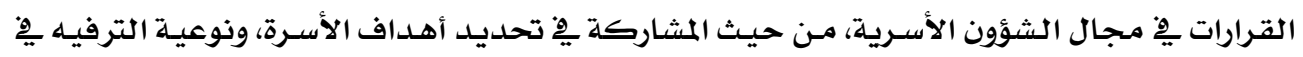

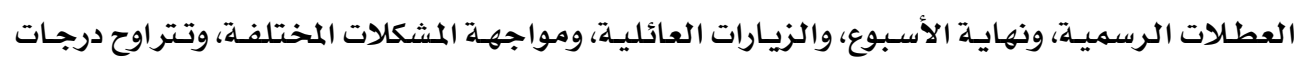
هذا المحور من (الrرابعاً: مقياس أساليب المعاملة الوالدولية : درجات :

قام النفيعي (1991) بإعداد هذا المقياس، وهو عبارة عن مقياس يقيس أسـاليب المعاملـة التي

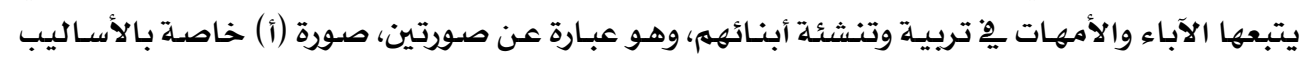

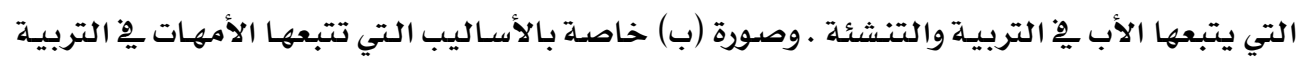

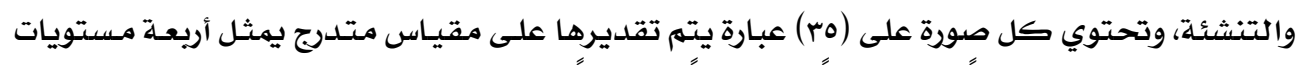

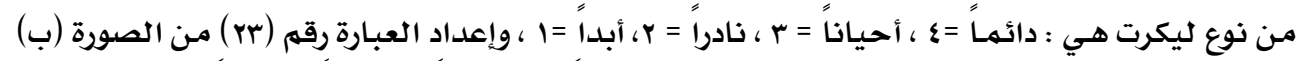

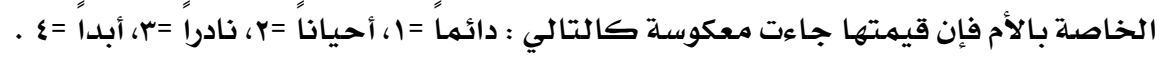

ويتضمن المقياس ثلاثة مقاييس فرعية لأساليب المعاملة الوالدية وهي :

Power Assertion : المقياس الأول : الأسلوب العقابي أو تأكيد القوة

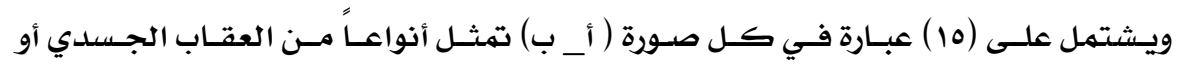

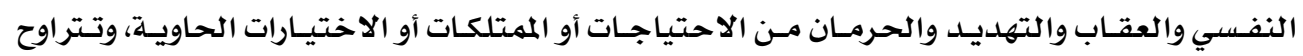

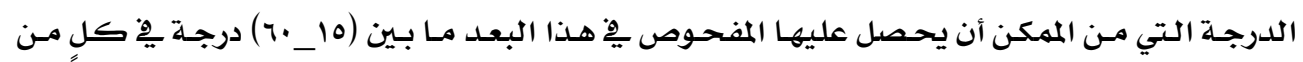

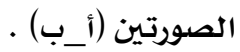

rove withdrawal : المقياس الثاني : أسلوب سحب الحب أو الحرمان العاطفي

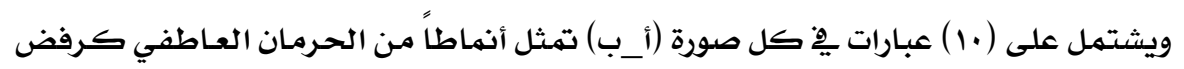

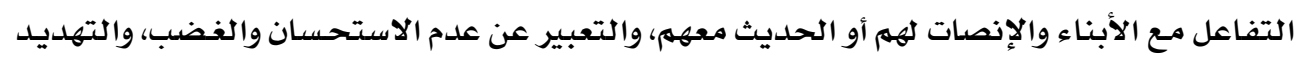

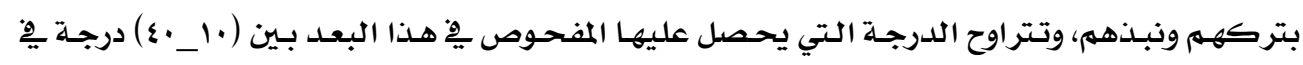
كلٍ من الصورتين (أ_ب).

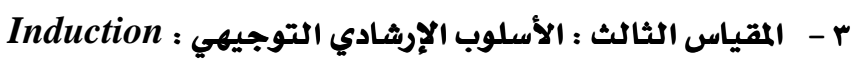

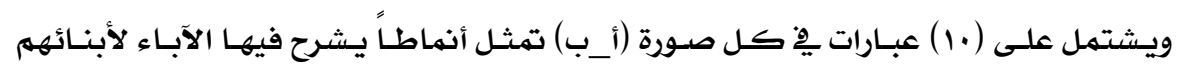

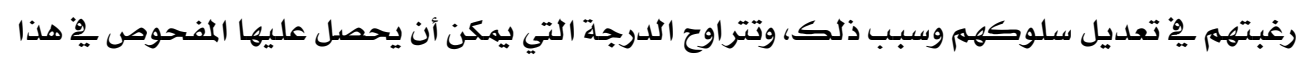

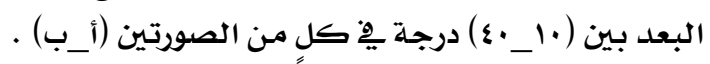
صلدق الاستبيان : يقصد به " قدرة الاستبيان على قياس ما وضع لقياسه " أو السمة المراد قياسها، كمها يهـدف

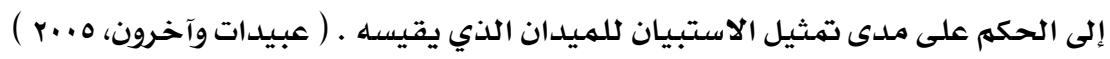


بعد توزيع الاستبيان على العينة الاستطلاعية، وإجراء بعض التعديلات فيـه، قامـت الباحثة

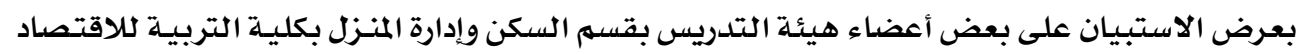

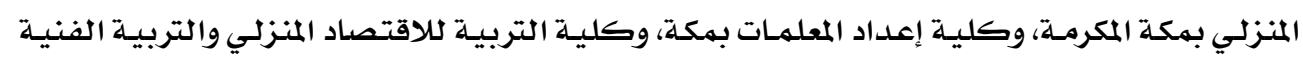

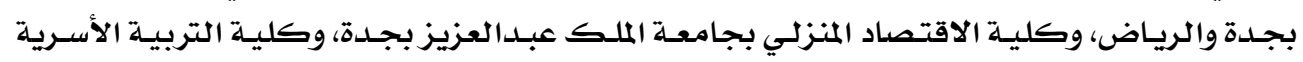

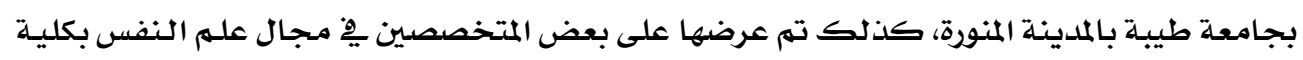

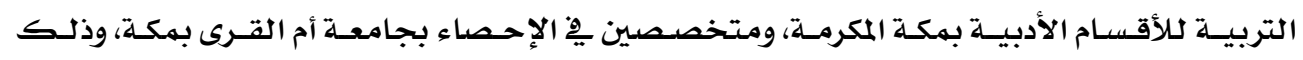

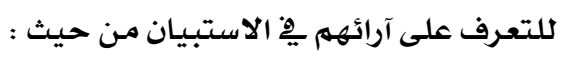

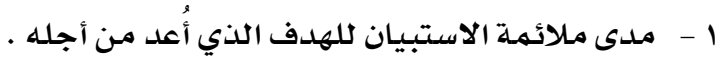

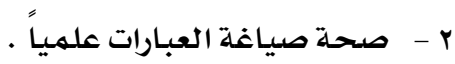

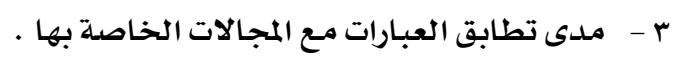

ثبات الاستبيان :

يقصد بثبات الاستبيان " النسبة بين تباين الدرجة على المقياس التي تشير إلى الأداء الفعلي

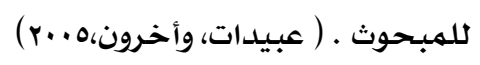

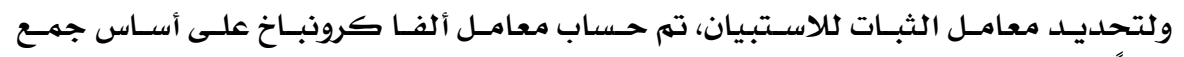

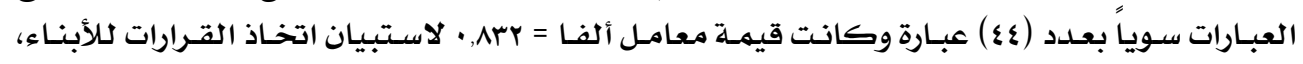

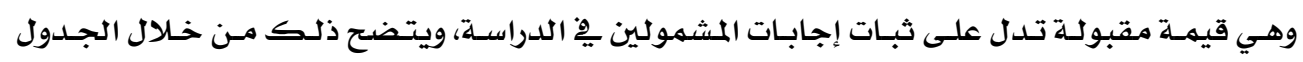

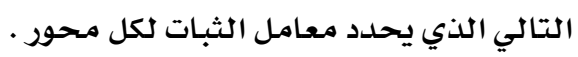

\begin{tabular}{|c|c|c|}
\hline معدل الثبات & عدد العبارات & المحسـاور \\
\hline., $0 \wedge 9$ & 7 & قضاء وقت الفراغ \\
\hline$\cdot$, . 0. & $\varepsilon$ & الغـذاء \\
\hline., OYI & 0 & الأصدقـاء \\
\hline$\cdot, \mathrm{V} \backslash \mathrm{A}$ & $\wedge$ & التعلسيم \\
\hline., 701 & $\checkmark$ & الملبـس \\
\hline ת & $r$ & المواصـلات \\
\hline .011 & 0 & العلاقات الاجتمـاعية \\
\hline$\cdot, 701$ & $\checkmark$ & شئون الأسـرة \\
\hline • Arr & $\varepsilon \varepsilon$ & اتخاذ القرارات ككل \\
\hline
\end{tabular}

\section{جدول (1)}


يتضح من جدول (1) أن قيهم معـاملات الثبـات لمحساور استبيان اتخـاذ القرارات للأبنـاء ككل،

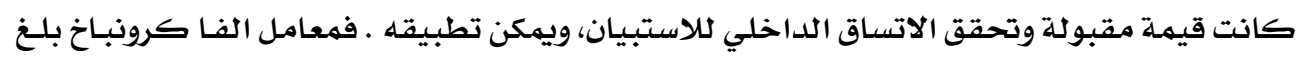
. (•, $($ Nrr)

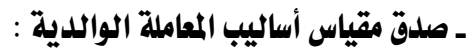

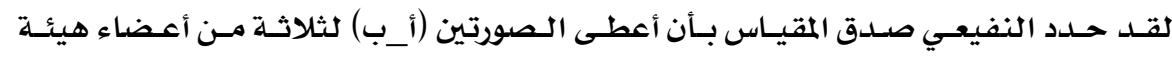

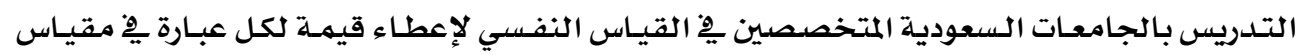

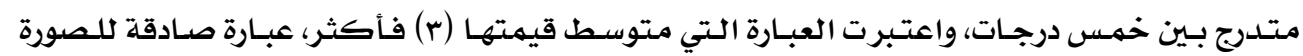

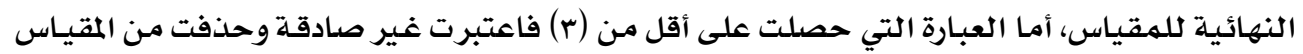

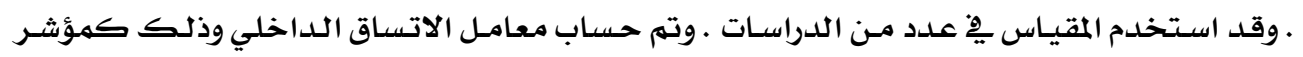

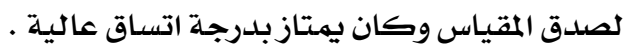

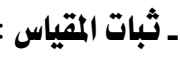

يمتاز المقياس بلدرجة ثبات عالية، حيث تم حسـاب معاملـ الثبـات لعينـة مـن طـلاب الجـامعـات

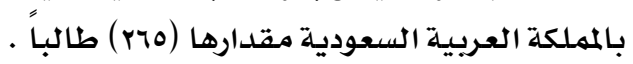

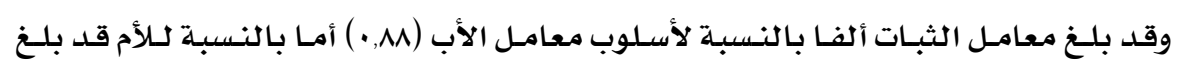

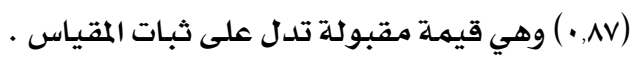

$$
\begin{aligned}
& \text { ويتضح ذلك من خلال الجدول التالي : }
\end{aligned}
$$

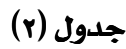

\begin{tabular}{|c|c|c|}
\hline معامل الثبات & عدد العبـارات & الأسـاليـب \\
\hline$\cdot, \wedge 9$ & 10 & الأسـلوب العقابي \\
\hline$\cdot, V \varepsilon$ & 1. & أسلوب سـحب الحب \\
\hline$\cdot, \wedge \cdot$ & 1. & الأسلوب الإرشـادي التوجيهي \\
\hline$\cdot, \Lambda \Lambda$ & ro & الأسـاليب ككل \\
\hline
\end{tabular}

جدول (r)

قيم معاملات الثبات لمقياس أساليب المعاملة الوالدية للأم

\begin{tabular}{|c|c|c|}
\hline معامل الثبـات & عدد العبـارات & الأسـاليـب \\
\hline$\cdot, \wedge 9$ & 10 & الأسلوب العقابي \\
\hline אד, • & 1. & أسلوب سـحب الحب \\
\hline$\cdot, \mathrm{V} \wedge$ & 1. & الأسلوب الإرشادي التوجيهي \\
\hline$\cdot, \Lambda \mathrm{V}$ & 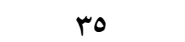 & الأسـاليـ ككل \\
\hline
\end{tabular}




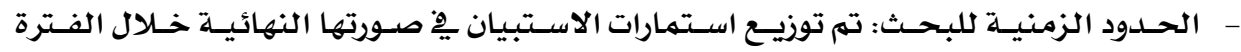

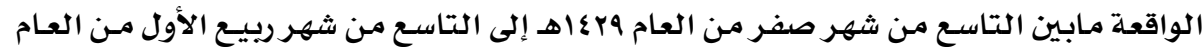

الحدود المكانية:تم تطبيق أدوات البحث على عينة قصدية من طلاب وطالبـات المرحلـة الثانويـة

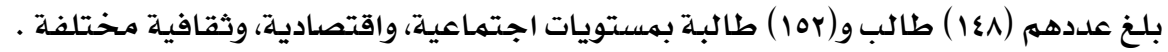

\section{0- المعالجات الإهصائية:}

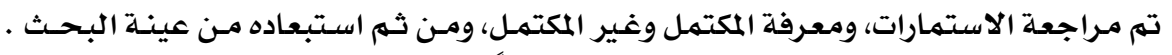

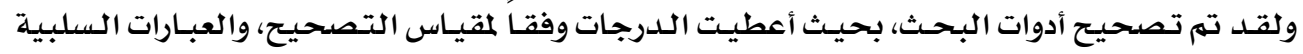

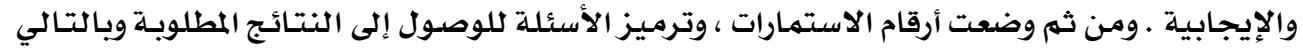

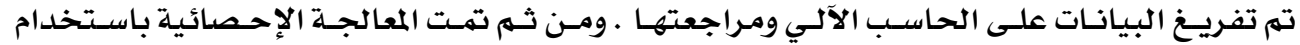

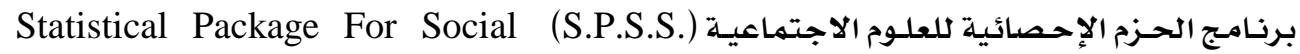

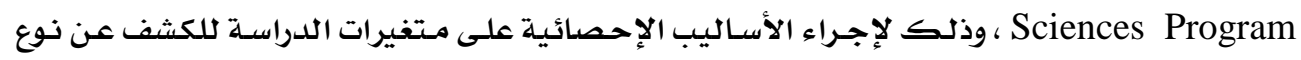

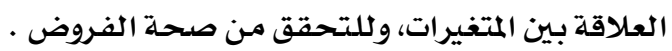

$$
\begin{aligned}
& \text { وقد تم إجراء المعالجات الإحصائية التالية : } \\
& 1 \text { - حساب النسب المئوية والتكرارات . } \\
& \text { r - جساب المتوسط الحسابي والانحراف المعياري . }
\end{aligned}
$$

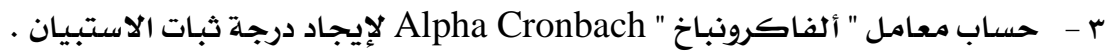

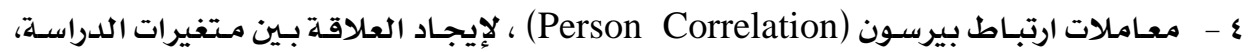

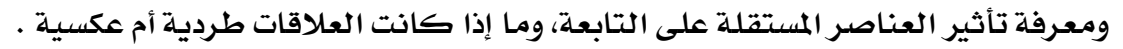

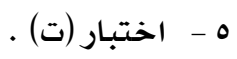

1 - مصفوفة معاملات الارتباط من اجل استخراج النتائج ومناقشتها وتفسيرها.

أولا: النتائج الوصفية الخاصة بالبيانات العامة للأسرة:

\begin{tabular}{|c|c|c|}
\hline النسبـة المئويـة & العـلـد & مـدة الززواج \\
\hline 77 & 191 & أقل مـن ·r سنـة \\
\hline$r \cdot r$ & 71 & من ·س لأقل من هب سنـة \\
\hline Ir,V & $\varepsilon 1$ & من هب سنـة فأكثر \\
\hline$\% 1 \cdots$ & r.. & المجهموع \\
\hline
\end{tabular}

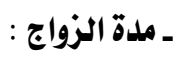

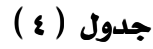

التوزيـع النسبي لعينة البحث تبعاً لمدة الزواج للوالدين (ن =...r) 


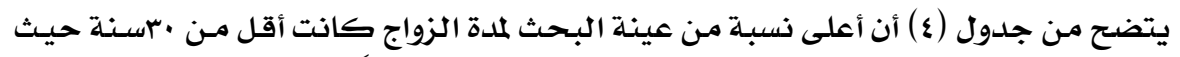

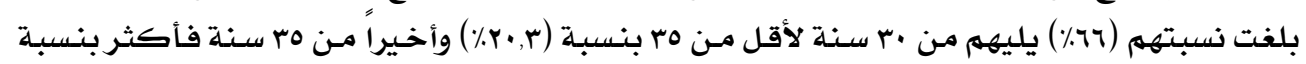
. $(\%, r, v)$

ـ المستوى التعليمي للوالدين : المالئ.

جدول (0)

التوزيـع النسبي لعينة البحث تبعاً للمستوى التعليمي للوالدين (ن =...r) (ه)

\begin{tabular}{|c|c|c|c|c|}
\hline \multicolumn{2}{|l|}{ الأم } & \multicolumn{2}{|l|}{ الأب } & \multirow{2}{*}{ للمستوى التعليمي } \\
\hline النسبة المئوية & العلد & النسبـة المئويـة & العدد & \\
\hline $17, r$ & $\varepsilon 9$ & $7, V$ & $r \cdot$ & أمى \\
\hline$r \cdot r$ & 71 & $1 \Lambda, r$ & 00 & ابتدائـي \\
\hline IA,V & 07 & $1 \varepsilon$ & $\varepsilon r$ & متوسط \\
\hline $19, r$ & $0 \wedge$ & $\mid \Lambda, V$ & 07 & ثانـوي \\
\hline$r, V$ & $\wedge$ & $7, r$ & 19 & دبلوم \\
\hline$M, r$ & 00 & $r r, V$ & vi & جامعي \\
\hline$\varepsilon, \varepsilon$ & ir & Ir,r & rv & فوق الجـامعي \\
\hline$\% 1 \ldots$ & r... & $\% 1 \ldots$ & r... & المجمـوع \\
\hline
\end{tabular}

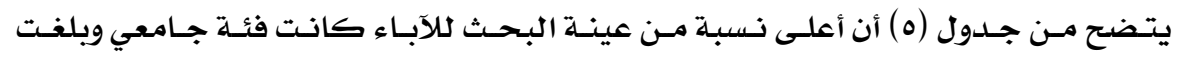

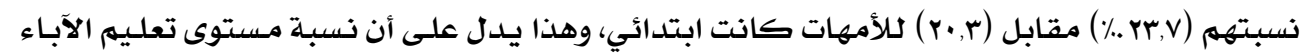

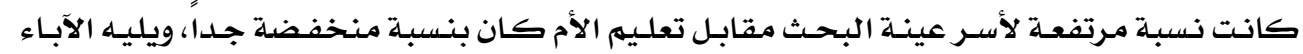

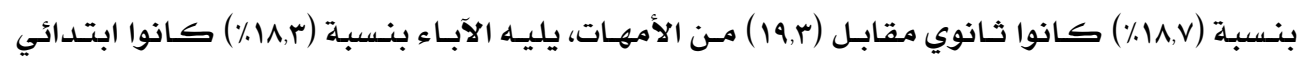

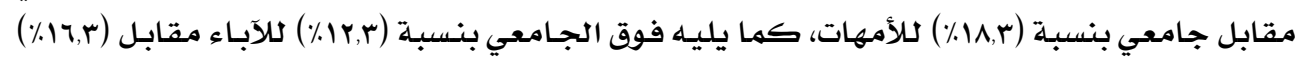

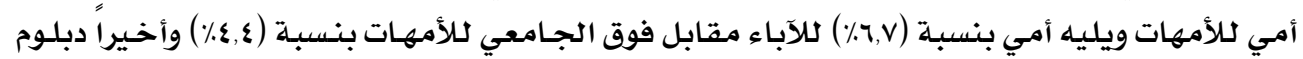

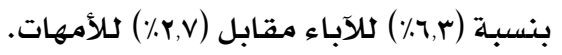




\begin{tabular}{|c|c|c|c|c|}
\hline \multicolumn{5}{|c|}{ 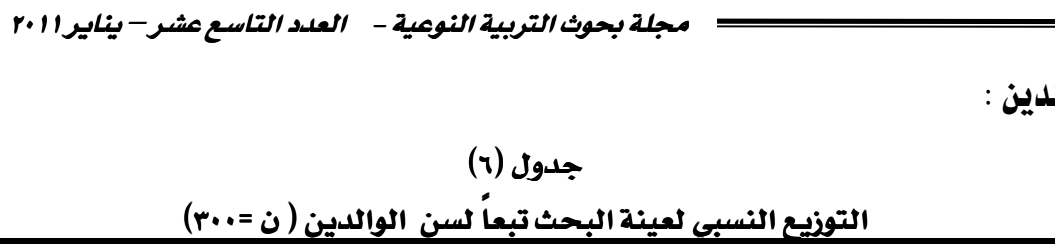 } \\
\hline \multicolumn{2}{|l|}{ الأم } & \multicolumn{2}{|c|}{ الأب } & \multirow{2}{*}{ عمـر الوالديـن } \\
\hline النسبــة المئويـة & العدد الع & النسبــة المئويـة & العدد الع & \\
\hline $1 \&, V$ & $\varepsilon \varepsilon$ & 1 & r & أقل مـن هب سنـة \\
\hline$\Delta \Delta, V$ & $17 V$ & 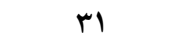 & q & مـن هب سنـة لأقل مـن هعسنـة \\
\hline ry & VA & $\{0, V$ & IrV & من 0ـ سـنـة لأقل مـن 00سنـة \\
\hline$r, 7$ & 11 & $1 \wedge, V$ & 07 & من 00 سنـة لأقل من 07سنـة \\
\hline- & - & $r, 7$ & 11 & من \\
\hline$\% 1 \cdots$ & r.. & $\% 1 \ldots$ & r... & المجمـوع \\
\hline
\end{tabular}

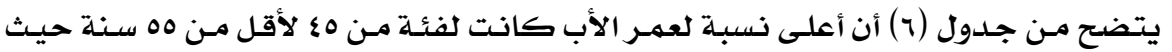

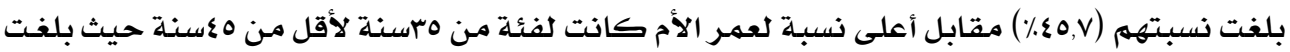

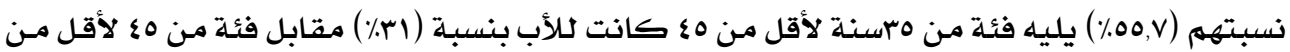

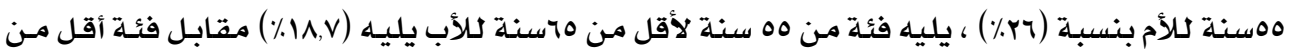

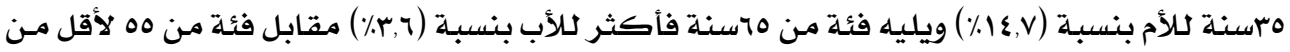

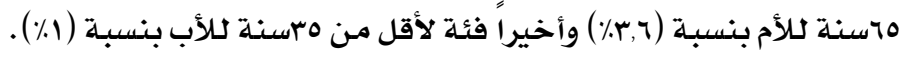

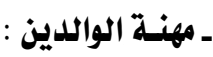

\section{(v) جدول)}

التوزيع النسبي لعينة البحث تبعاً لمهنة الوالدين ( ن =..r)

\begin{tabular}{|c|c|c|c|c|}
\hline \multicolumn{2}{|l|}{ الأم } & \multicolumn{2}{|l|}{ الأب } & \multirow{2}{*}{ مهنــة الوالديـن } \\
\hline النسبــة المئويـة & العدد & النسبــة المئويـة & العلدد & \\
\hline תוr & $r \varepsilon \varepsilon$ & $\wedge$ & $r \varepsilon$ & لا يعهـل \\
\hline IY,TV & rs & $\varepsilon \varepsilon$ & IrY & موظف حكومىي \\
\hline 1, 1, 1 & $\varepsilon$ & r & $\varepsilon$. & قطاع خاص \\
\hline Y,TV & $\wedge$ & $r \cdot$ & 7. & أعمال حرة \\
\hline$r$ & 7 & $1 \varepsilon, V$ & $\varepsilon \varepsilon$ & متقـاعد \\
\hline$\% 1 \ldots$ & r.. & $\% 1 \ldots$ & r.. & المجهموع \\
\hline
\end{tabular}

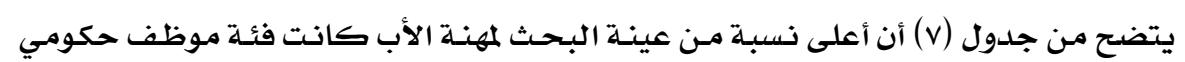

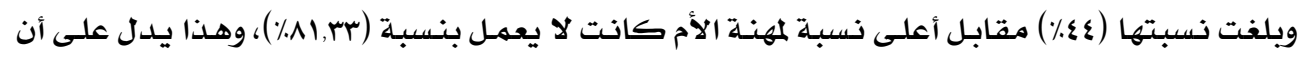


الغالبيـة العظمـى مـن أمهـات عينـة البحـث لا يعملـن بـأي قطـاع مـن القطاعـات المهنيـة أو الوظيفيـة،

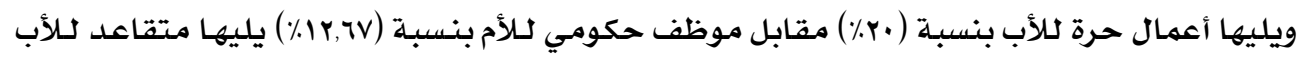

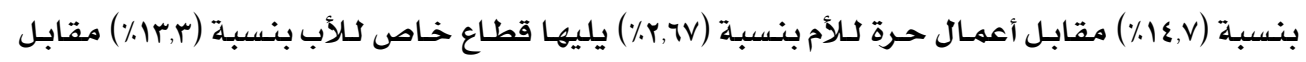

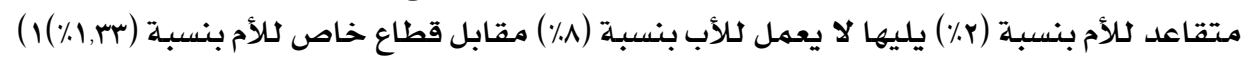
ـ اللدخل الشهري الكلي للأسرة :

\section{جدول (A)}

التوزيع النسبي لعينة البحث تبعاً للدخل الشهري للأسرة ( ن =...r)

\begin{tabular}{|c|c|c|}
\hline النسبـة المئوية & 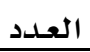 & الدخل الشهري للأسرة \\
\hline rı,V & 70 & أقل من ...0ץ ريال \\
\hline$I V, r$ & or & 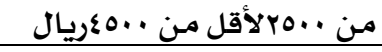 \\
\hline 19 & ov & من ..0ـ لأقل من ..07ريال \\
\hline ir & 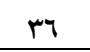 & من ...07 لأقل من ..01ريال \\
\hline $9, r$ & YM & 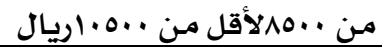 \\
\hline$r \cdot V$ & $7 r$ & من ... 1 فأكثر \\
\hline$\% 1 \ldots$ & r.. & المجموع \\
\hline
\end{tabular}

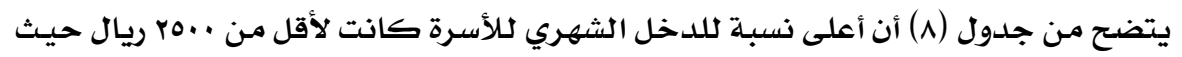

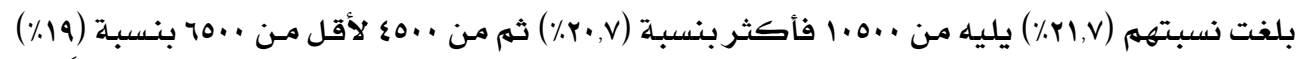

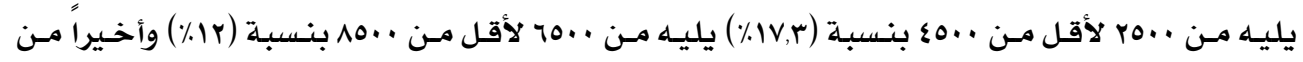

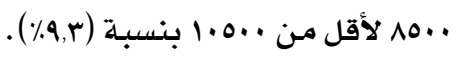

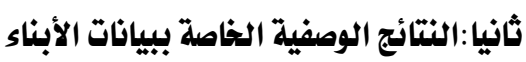
اـ النسوع :

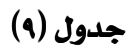

التوزيع النسبي لعينة البحث تبعاً لنوع الأبناء (ن =...r)

\begin{tabular}{|c|c|c|}
\hline النسبة المئوية & العـدد & النـوع \\
\hline$\varepsilon 9, r$ & $1 \leqslant \Lambda$ & ذكـر \\
\hline $0 ., \mathrm{V}$ & 10r & أنثى \\
\hline$\% 1 \ldots$ & r.. & المجمـوع \\
\hline
\end{tabular}

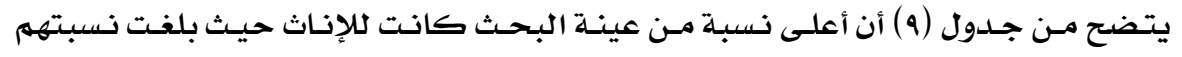

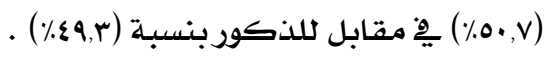


جدول (1.)

التوزيـع النسبي لعينة البحث تبعاً للعمر ( ن =...r)

\begin{tabular}{|c|c|c|}
\hline النسبـة المئويـة & 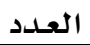 & العمـر \\
\hline 1 & r & أقل مـن 10 سنــة \\
\hline rq & $11 \mathrm{~V}$ & هاسنة لأقل من Vاسنة \\
\hline 7. & $1 \wedge$. & Vاسنـة فأكثر \\
\hline$\% 1 \ldots$ & r.. & المجمهوع \\
\hline
\end{tabular}

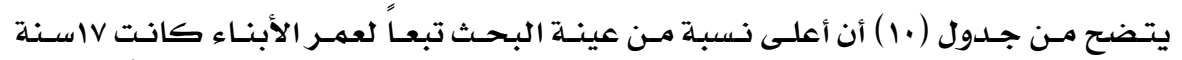

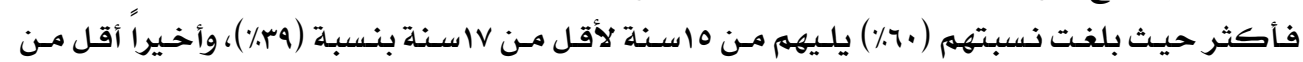

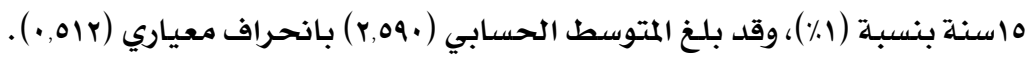

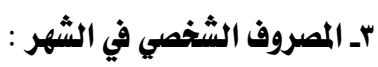

جدول (11)

التوزيع النسبي لعينة البحث تبعاً للمصروف الشخصي يو الشهر ( ن =...r)

\begin{tabular}{|c|c|c|}
\hline النسبة المئوية & 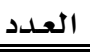 & المصروف الشخصي ـِ الشهر \\
\hline$r q, v$ & 119 & أقل من · . اريـال \\
\hline$r q, r$ & $\Lambda \Lambda$ & من · . الأقل من ·• اريال \\
\hline Ir,v & $\varepsilon 1$ & مـن ·1 الأقل من ·. r ريال \\
\hline IV,r & or & من · · ريال فأكثر \\
\hline$\% 1 \ldots$ & $r .$. & المجمهوع \\
\hline
\end{tabular}

يتضـح من جدول (11) أن أعلى نسبة من عينة البحث كانت لمن يتقاضـون أقل مـن . . اريال

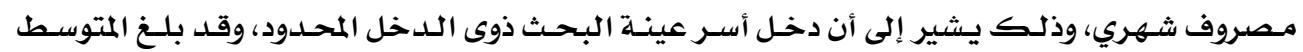

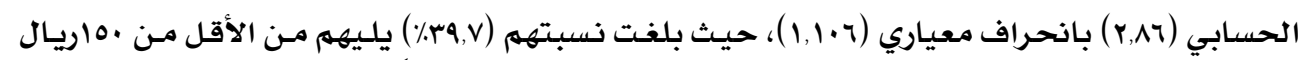

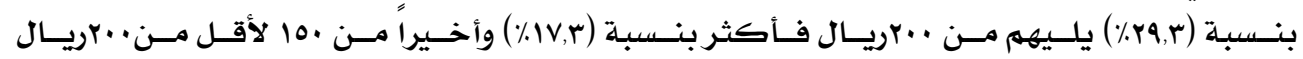

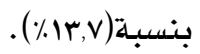

ثالثًا:النتائج في ضوك فروض البحث:

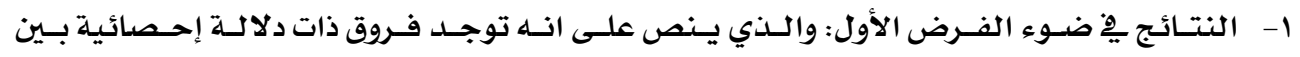

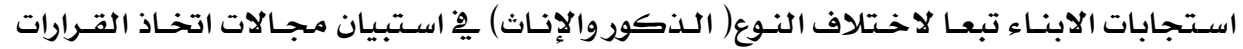

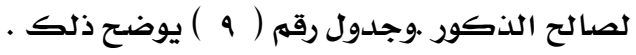


جدول (ir)

الفروق بين الذكوروالإناث ـِ اتخاذ القرارات للأبناء

\begin{tabular}{|c|c|c|c|c|}
\hline الدلالة & قهـة (ت) & الانحراف المعياري & المتوسط الحسسابي & النـوع \\
\hline \multirow{2}{*}{ دال عند مستوى ه •. . } & \multirow{2}{*}{$\& 1, r \varepsilon$} & 11,01 & qr, rq & ذ ذكور \\
\hline & & $11, \cdot \varepsilon$ & מצ, & إناث \\
\hline
\end{tabular}

يتبين من الجدول وجود فروق ذات دلالـة إحصائية عند مستوى ه •. •بـين الـذكور والإناث يِ

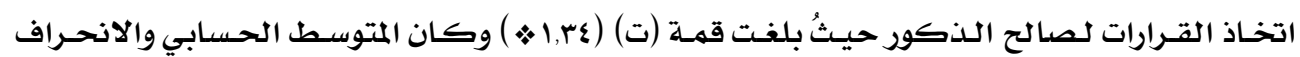

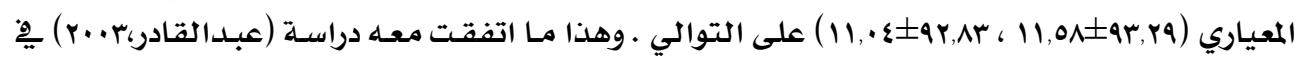

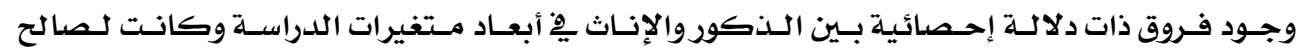

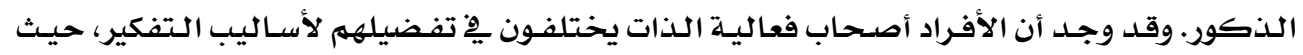

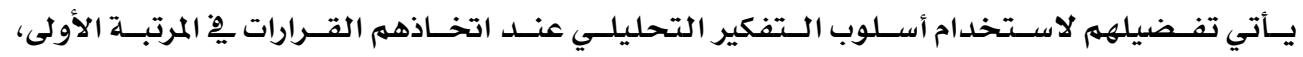

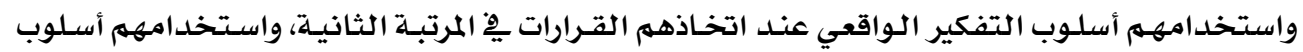

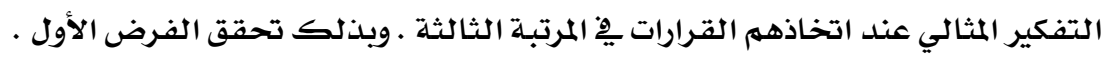

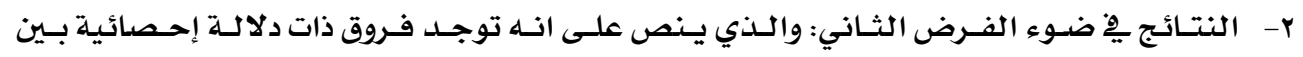

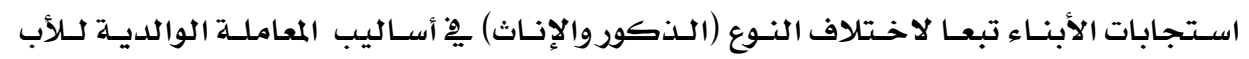

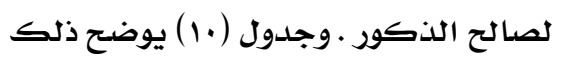

جدول (ir)

الفروق بين الذكوروالإناث يو أسلوب المعاملة الوالدية للأب

\begin{tabular}{|c|c|c|c|c|c|c|}
\hline \multirow[b]{2}{*}{ الدلادة } & \multirow[b]{2}{*}{ قمة (ت) } & \multicolumn{2}{|c|}{ إنـاث } & \multicolumn{2}{|c|}{ ذكـور } & \multirow[b]{2}{*}{ الأسـاليبب } \\
\hline & & الانحراف & المتوسط الحسابي & الانحراف & المتوسط الحسبابي & \\
\hline مستوى اله عند & o,ror $\nLeftarrow$ & T,०АV & $r I, V \varepsilon r$ & V,ArV & rq,YוT & الأسلوب العقابي \\
\hline مستوى الث عند & $\varepsilon, V) * \star \star$ & 0,009 & $r \cdot, 9 Y_{1}$ & Y.YYI & $r \leqslant,|\leqslant|$ & أسلوب سحب الحب \\
\hline مستوى اله عند & Y.१९৭ & $\varepsilon, 91 V$ & rr,VAr & $0,\{Y\}$ & Yo,OVE & الأســلوب الإرشـــادي \\
\hline مستوى اله عند & $0, \cdots \varepsilon * * *$ & $10, \cdot \mathrm{r}$ & 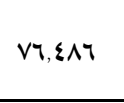 & $1 V, 0 \wedge 9$ & 10,৭rr & الأسـاليب ككل \\
\hline
\end{tabular}




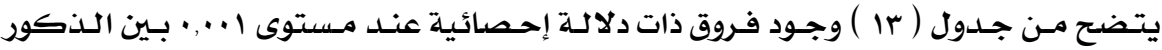

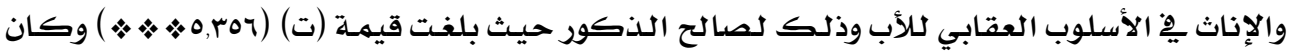

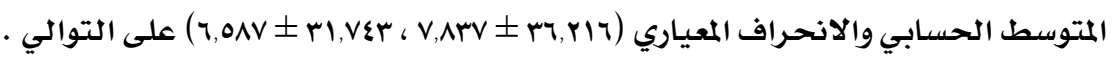

كما تبين من الجدول وجود فروق ذات دلالـة إحصائية عند مستوى دال ا +., · بـين الذكور

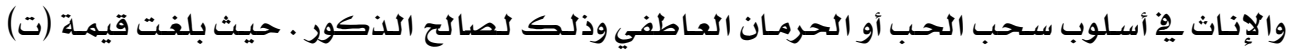

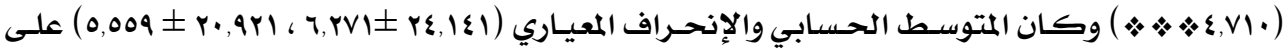

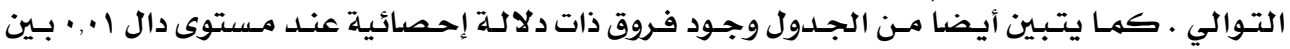

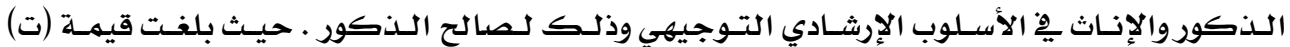

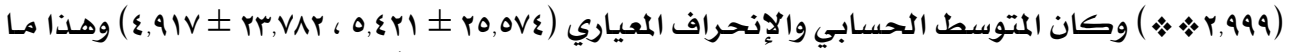

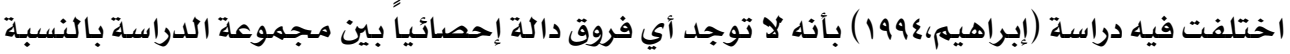

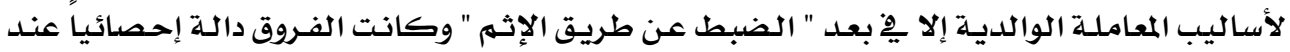

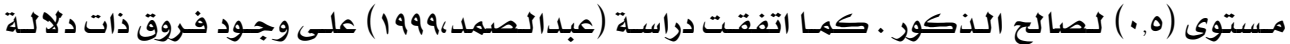

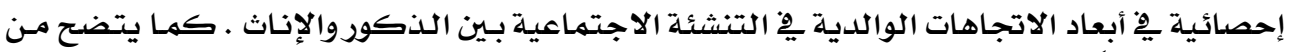

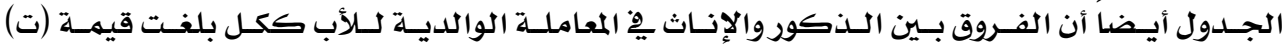

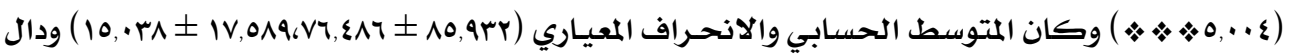

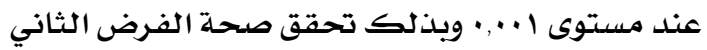

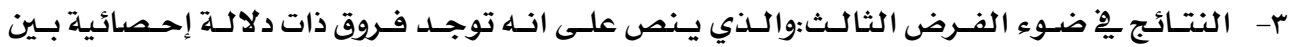

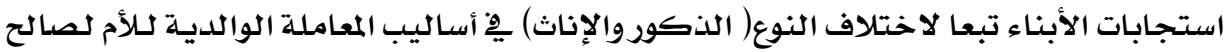
الذكور.

$$
\text { جدول (1) }
$$

الفروق بين الذكوروالإناث يِ أسلوب المعاملة الوالدية كلأم

\begin{tabular}{|c|c|c|c|c|c|c|}
\hline \multirow[b]{2}{*}{ الدلالة } & \multirow[b]{2}{*}{ قهـة (ت) } & \multicolumn{2}{|c|}{ إنـاث } & \multicolumn{2}{|c|}{ ذكور } & \multirow[b]{2}{*}{ الأسـاليـب } \\
\hline & & الانحراف & المتوسط الحسابي & الانحراف & المتوسط الحسبابي & \\
\hline غير دال & .9 .90 & $7, \varepsilon \varepsilon$. & 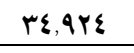 & $V, r \wedge \varepsilon$ & r & الأسلوب العقابي \\
\hline غير دال & $\cdot \leqslant 0$. & $\varepsilon,|r|$ & Y\&, Yาq & $\varepsilon, V_{1}$. & $r \varepsilon, 0 \ldots$ & أسلوب سحب الحب \\
\hline غير دال & 1,1 . & 0,1 N & $Y \varepsilon, \wedge \vee 0$ & 0,079 & ro, & الأســــلوب الإرشـــــــي \\
\hline غير دال &., $70 \varepsilon$ & $1 \varepsilon, \cdot q$ & $\Lambda \mathrm{N}, \Lambda \mathrm{V} \mathrm{O}$ & 17,Vir & $\Lambda 0, \cdot 1 \mu$ & الأساديب ككل \\
\hline
\end{tabular}

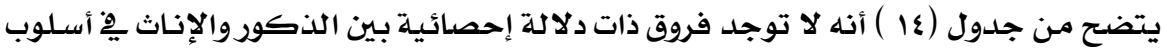

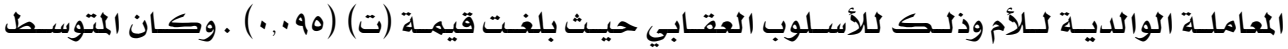

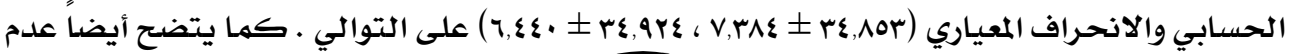




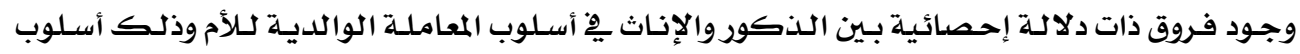

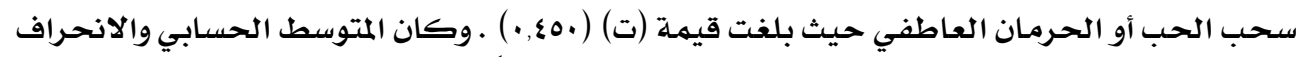

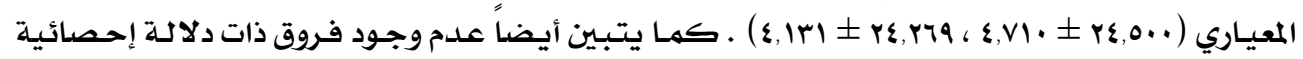

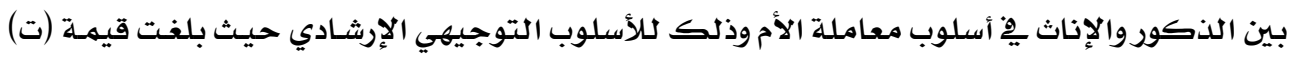

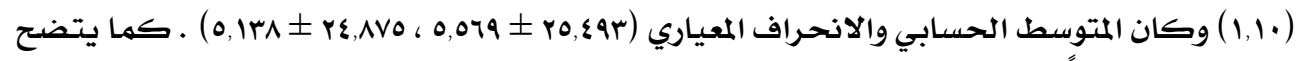

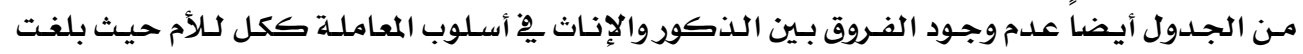

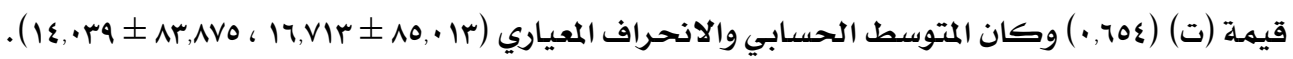

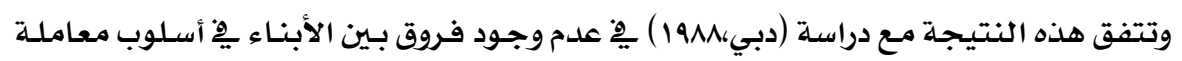

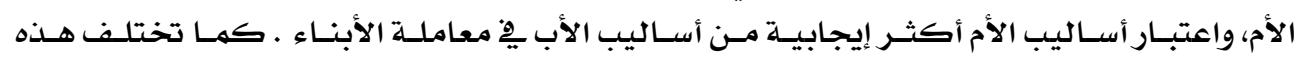

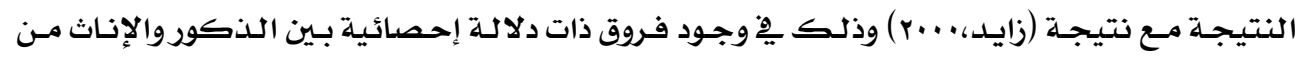

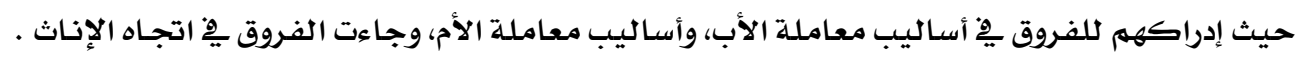

$$
\text { وبذلك لهم يتحقق الفرض الثالث . }
$$

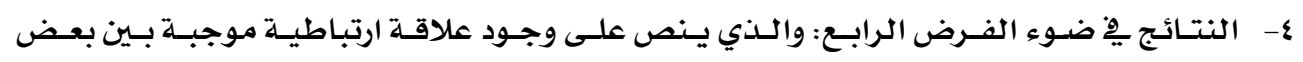

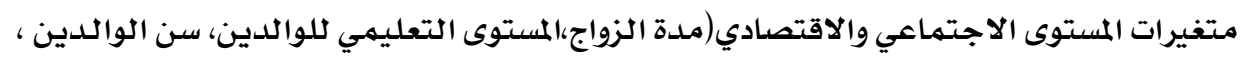

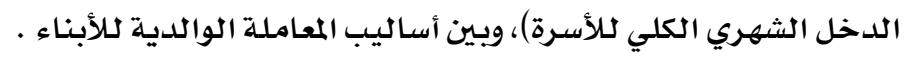

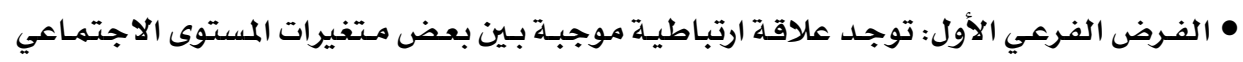

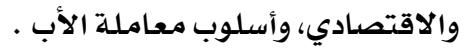

\section{جدول (10)}

\section{العلاقات الارتباطية بين بعض المتغيرات المستوى الاجتماعي والاقتصادي وأسلوب معاملة الأب (1)}

\begin{tabular}{|c|c|c|c|}
\hline الأسلوب الإرشادي & أسلوب سـحب & الأسلوب العقابي & المتغــيرات \\
\hline.$\cdot v r$ & $\$ 611 r$ &. $\mathrm{Y \mu}$ & مدة الزواج \\
\hline 6.70 & $\$ 1.1$ & $*$ * 107 & مستوى تعليم الأب \\
\hline 677 & ..r & $*$ ،IV & مستوى تعليهم الأم \\
\hline. .01 & $* * 119$ & .94 & سن الأب \\
\hline$\$ 11 \leqslant 0$ & $\$ 1111$ & $*$ * IVA & سن الأم \\
\hline $6.1 \mathrm{~V}$ & $\cdots 7$ & $\$ 11 \leqslant 7$ & الدخل الشهري الكلي للأسرة \\
\hline \&.ITE & $\$ .111$ & $* * 4 \cdot q$ & سن الأبناء \\
\hline
\end{tabular}




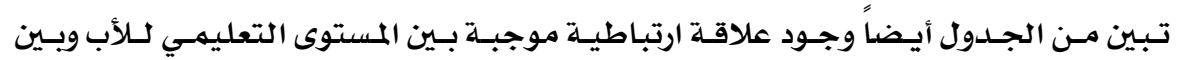

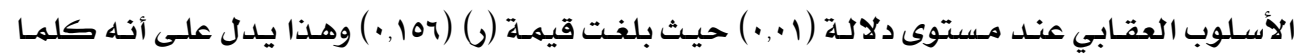

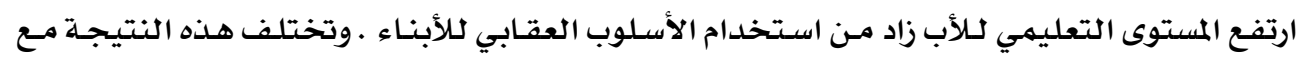

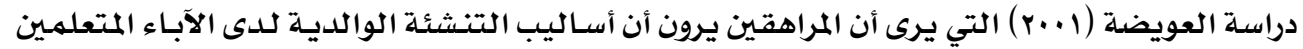

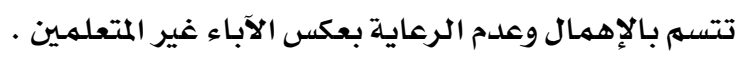

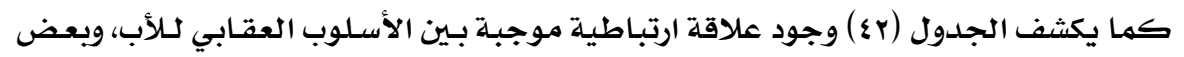

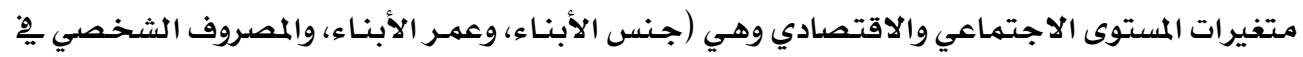

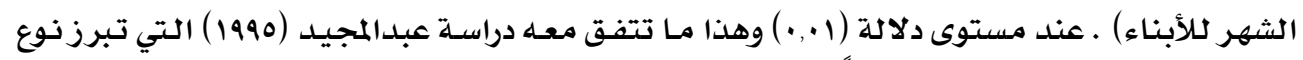

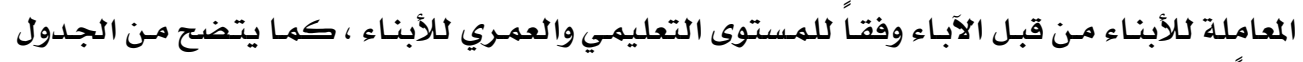

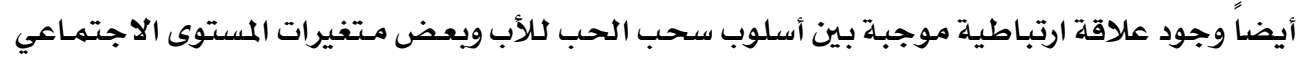

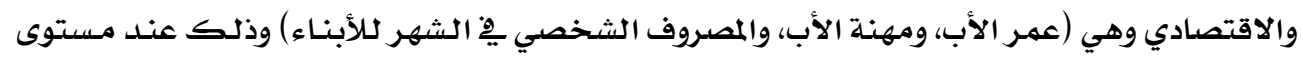

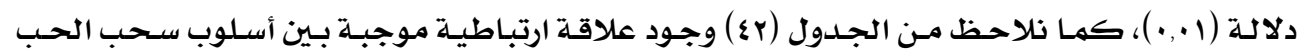

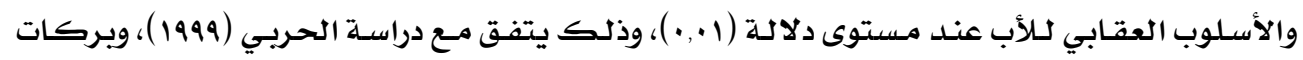

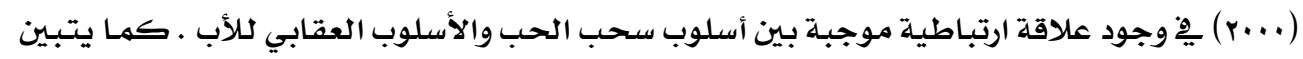

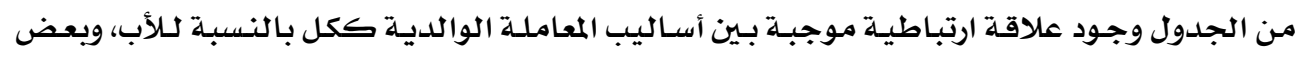

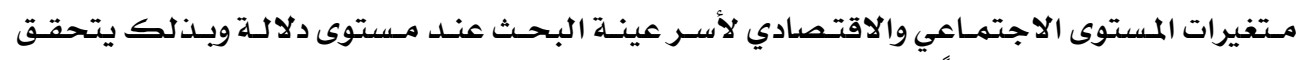

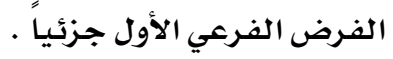

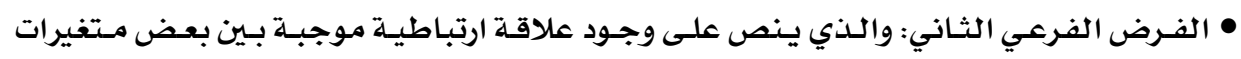

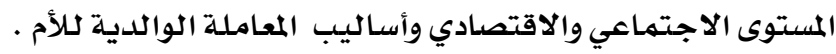

\section{جدول(17)}

العلاقات الارتباطية بين بعض المتغيرات المستوى الاجتماعي والاقتصادي وأسلوب معاملة الأم

\begin{tabular}{|c|c|c|c|}
\hline الأســلوب الإرشــادي & أســــلوب ســـــب & الأسلوب العقابي & 7 \\
\hline. .91 & ar. & ، $\because \uparrow$ & مدة الزواج \\
\hline$* * 17 \varepsilon$ & $* * 101$ & $* *$ IAV & مستوى تعليمى الأب \\
\hline $1 \cdot 1$ & $* 1111$ & $* * 1 \mathrm{M}$ & مستوى تعليم الأم \\
\hline * ، Irr & 6.01 & $\%$. IrA & سن الأب \\
\hline$* 11 r q$ & $، \cdot 14$ & $\ldots 1$ & سن الأم \\
\hline$*$ * l $\leqslant r$ & $\$(11 \varepsilon$ & 1.7 & الدخل الشهري الكلى للأسرة \\
\hline$* 111 r$ & $*$ ، IYY & $* 110$. & سن الأبناء \\
\hline
\end{tabular}

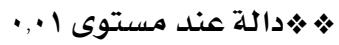

* داله عند مستوى 0.، 


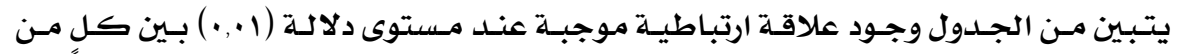

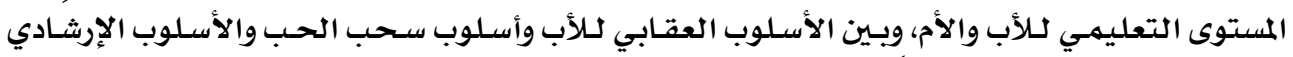

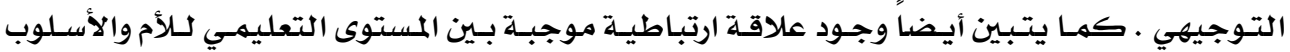

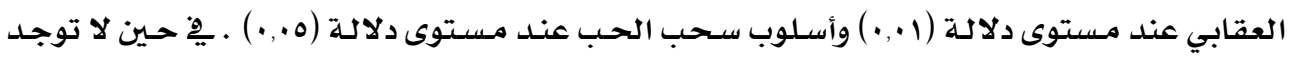

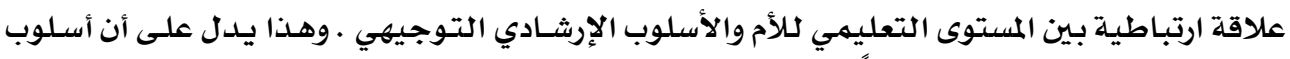

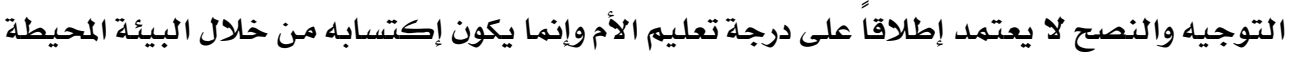

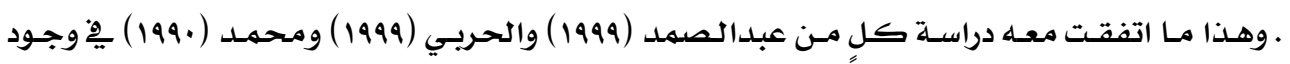

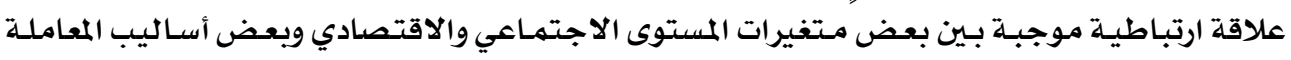
الوالدية كلأبناء .

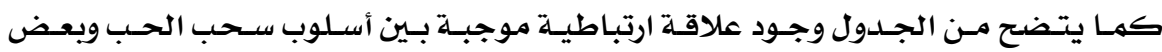

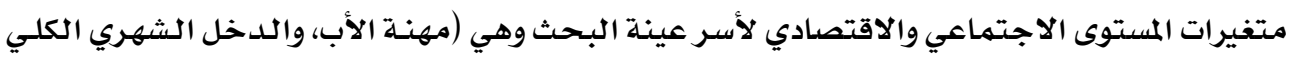

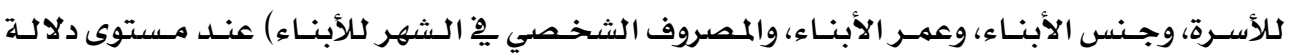

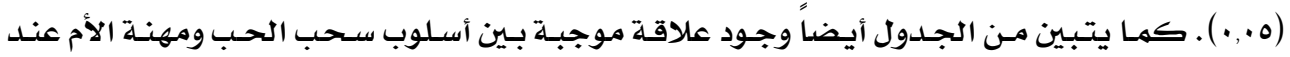

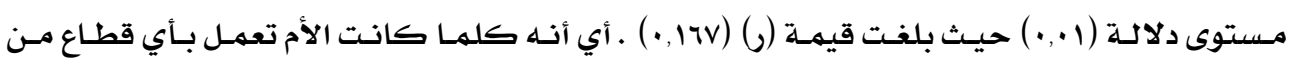

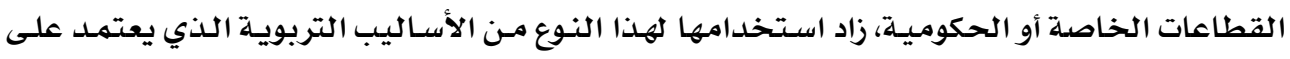

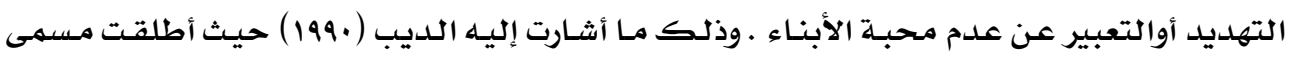

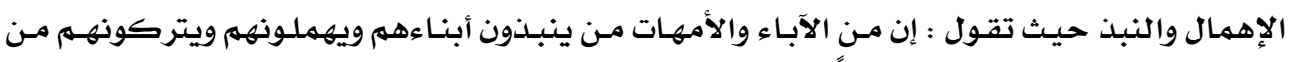

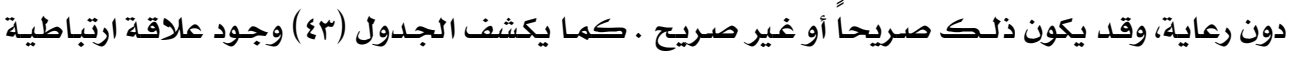

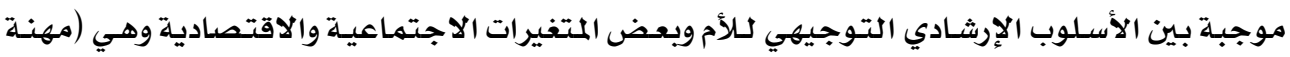

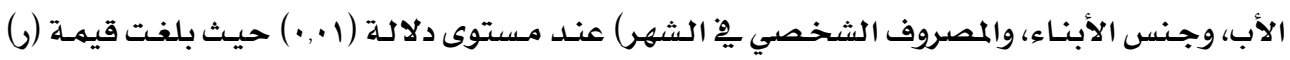

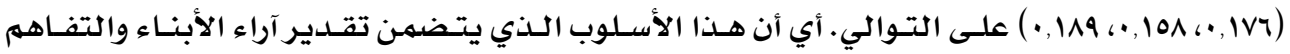

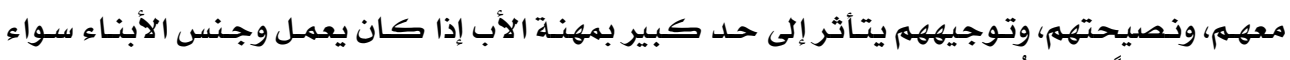

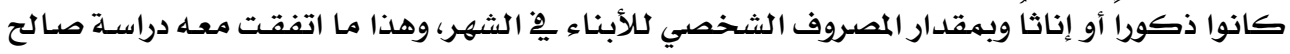

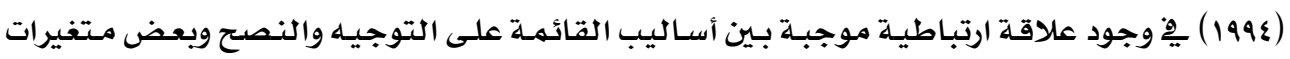

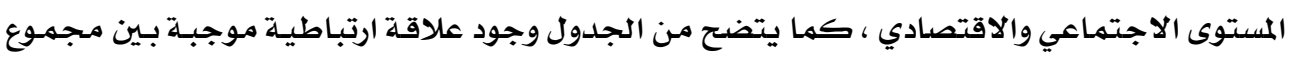

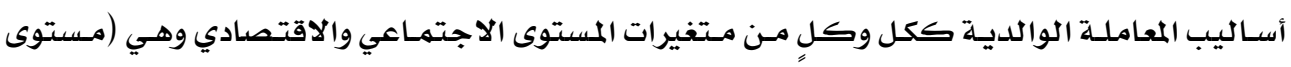

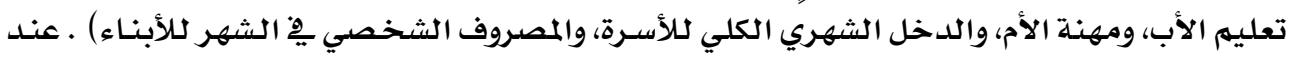

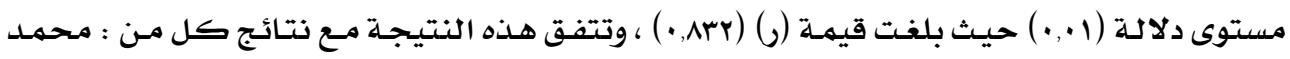

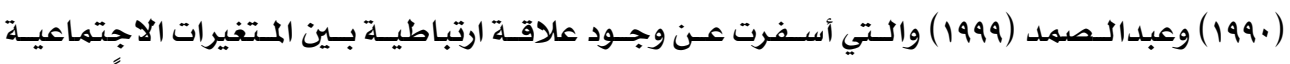

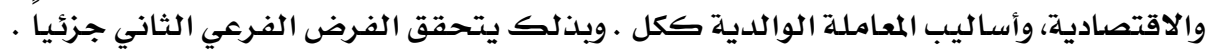




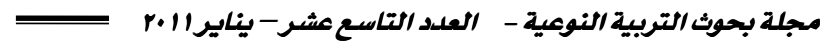

ه- الفرض الخـامس : والـذي يــص على وجـود علاقة ارتبـاطيـة موجبـة بـين أسـلوب المعاملـة الوالديـة وبعض مجالات اتخاذ الأبناء لقراراتهم فِ المرحلة الثانوية . • الفرض الفرعي الأول : ينص على وجـود علاقة ارتباطيـة موجبـة بـين أسـاليب المعاملـة الوالديـة

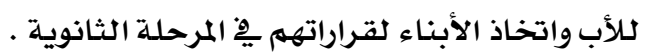

(iv) جدول)

العلاقات الارتباطية بين أساليب المعاملة الوالدية للأب ومجالات اتخاذ القرارات للأبناء

\begin{tabular}{|c|c|c|c|c|c|c|c|c|c|}
\hline مجالات القرارات ككل & $\begin{array}{l}\text { الشؤون } \\
\text { الأسرية } \\
\end{array}$ & الاجتماعلاعية العات & مجال & مجال & مجال & مجال & مجال & | قضاء وقت & المياس \\
\hline$\bullet \wedge \varepsilon$ & 6.14 & 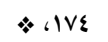 & 6.87 & **rrI & 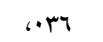 & $\because 199-$ &., $100-*$ & a. $\leqslant 0-$ & الأسلوب العقابي \\
\hline$* \$ 179$ & $* * r .0$ & $* *$ * r9o & $1 \cdot 1$ & * * trrt & $a \cdot r$ & - אדים. & $\cdot 119$ & .014 & أسلوب سحب الحب \\
\hline$* *$ rVA & * * rro & $* *$ \% & $* \$ 171$ & **หrTa & $* *$ *IT & . $\leqslant 0$ & ، V v & 8.179 & الأسلوب الإرشادي التوجييي \\
\hline$* * 17 \varepsilon$ & $8.1 \leqslant V$ & $* *$ irV. & $\$ 1119$ & * \& YTY & $\$ 1110$ & $1.00-$ & $\cdot$-16 $^{-}-$ &. .17 & الأساليب ككل \\
\hline
\end{tabular}

يتضـح مـن جـدول وجـود علاقـة ارتبـاطيـة سـالبـة بـين الأسـلوب العقـابي لـلأب، واتخـاذ الأبنـاء

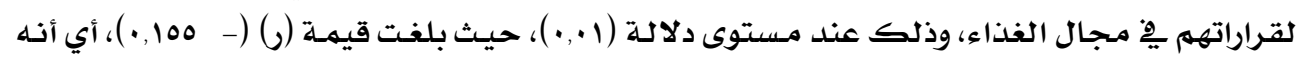

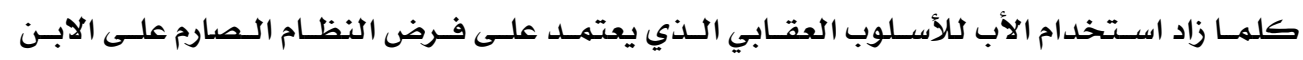

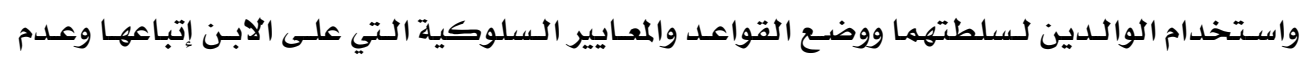
الحيـاد عنها، قلل ذلك من قدرة الابن على اتخاذ قراراته يْ مجال الغذاء الذي يتمثل يْ اختيـار الابن

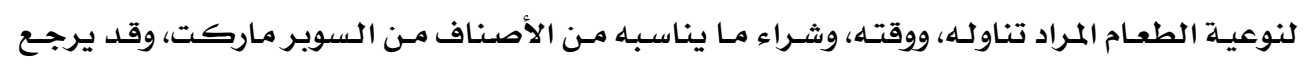

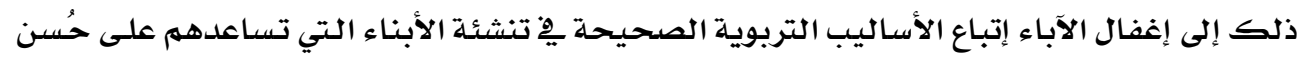

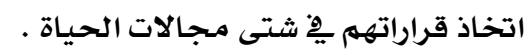

كما يـلاحظ من الجدول وجود علاقة ارتبـاطيه موجبـة بـين الأسـلوب العقـابي واتخـاذ الأبنـاء

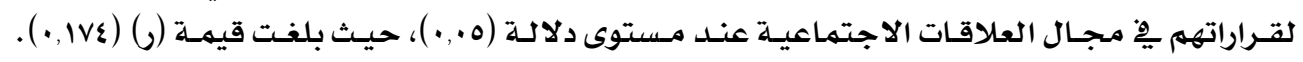

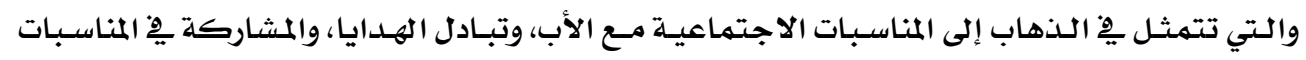

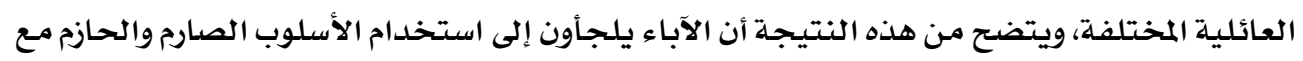

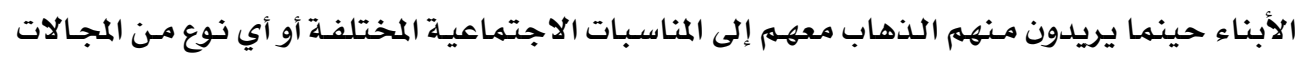

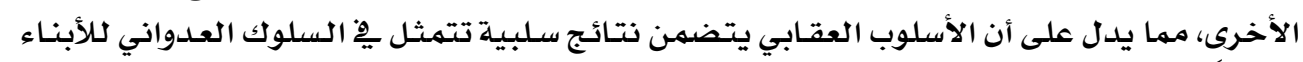

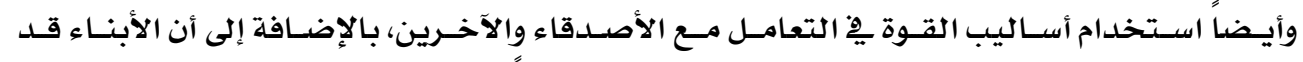

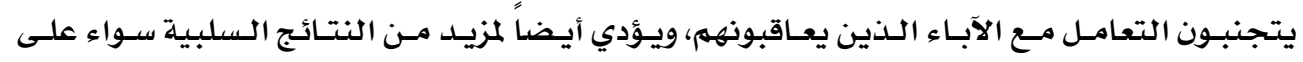
المستوى النفسي أو الاجتماعي أو على مستوى طبيعة العلاقة بين الآباء والأبناء .

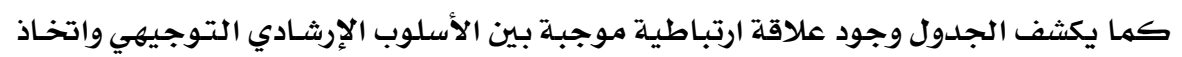

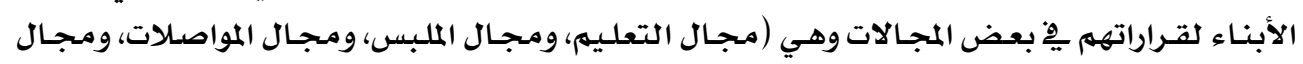




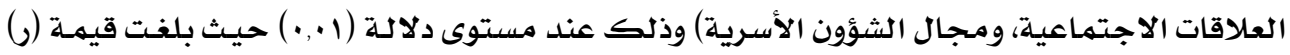

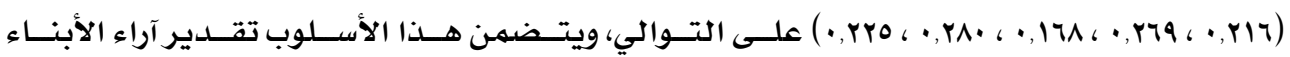

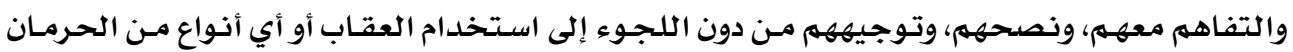
العاطفي

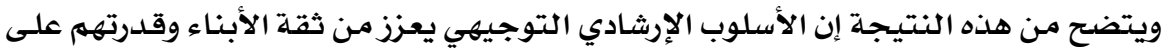

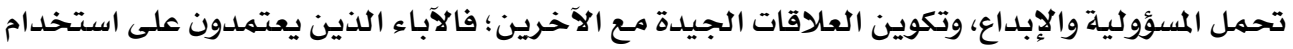

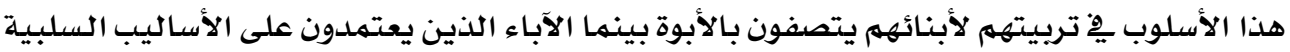

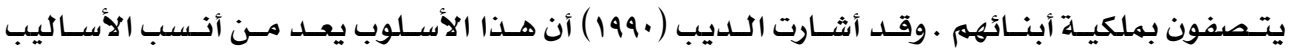

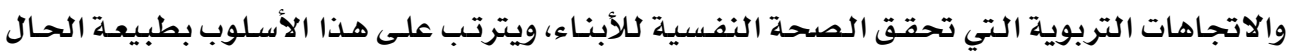

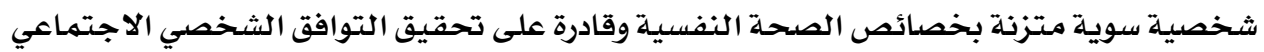

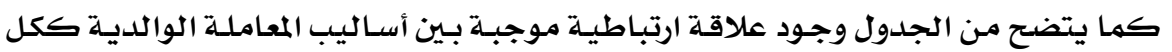

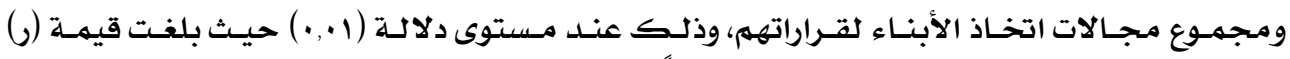

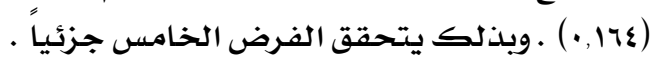

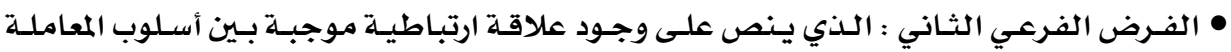

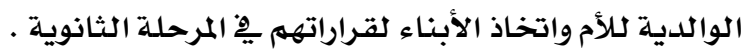

جدول(1)

\section{العلاقات الارتباطية بين أساليب المعاملة الوالدية كلأم ومجالات اتخاذ القرارات كلأبناء}

\begin{tabular}{|c|c|c|c|c|c|c|c|c|c|}
\hline |القرارات & الأسؤون & | العجاجتال & مجال & مجال & التعليم & الأصدقاء & مجال & قماء وقال & \\
\hline$\therefore \wedge 1$ & ، Or & $* 10 \%$ & 6.09 & r... & .99 & $\because v v_{-}$ & .rr, - & .01 & الأسلوب العقابي \\
\hline $.9 v$ & .94 & $* * r \cdots$ & ( & \&.10Y & .70 & $\therefore 11$ & $.0 V_{6}-$ & $\cdot v Y_{6-}$ & أسلوب سحب الحب \\
\hline ، 1.4 & 6117 & $* *$ TST & ( & $\$ .177$ & $\therefore$ rY & $\therefore \vee r r$ & $\cdot v \cdot c-$ & . & الأسلوب الإرشادي التوجييي \\
\hline .91 & .91 & $* *$.110 & CYY & $* *$, 19\& & . or & $\therefore \wedge$. & $\therefore 71$ & - & الأساليب ككل \\
\hline
\end{tabular}

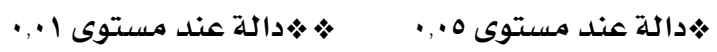

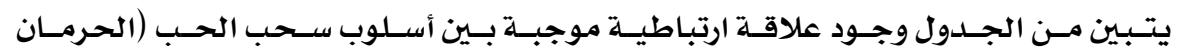

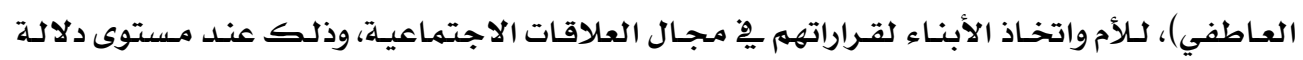

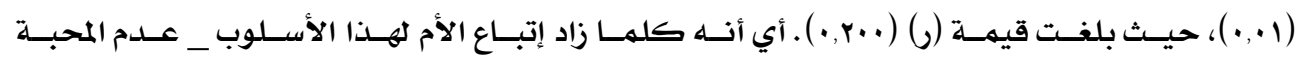

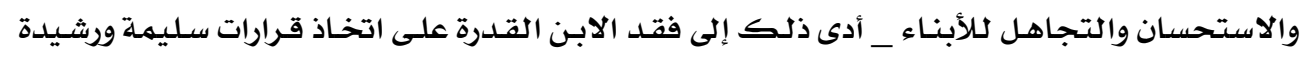

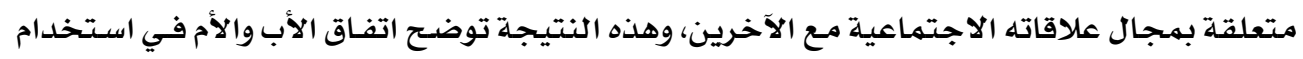

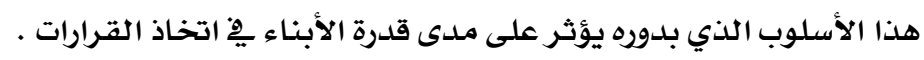


مجلة بحوث التربية النوعية - العلد التاسع عشر - يناير المبر

ِِّ حين ترى الباحثة أن الحب هـو القاسـم السلوكي والعـاطفي والإنساني المشترك لتعامل

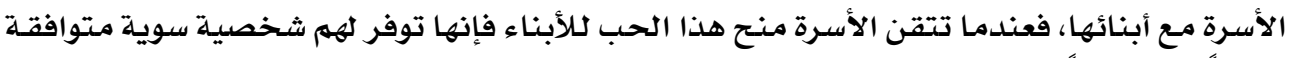

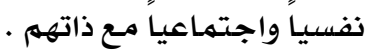

كما يـلاحظ من الجدول عدم وجود علاقة ارتباطية بـين الأسـلوب الإرثـادي التتوجيهي لـلأم

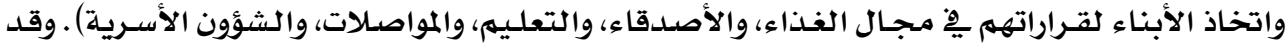

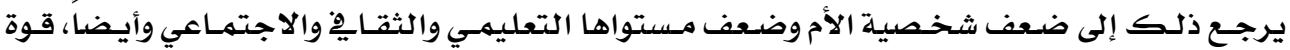
سلطة الأب مها يؤدي إلى عدم تأثيرها على أبنائها يِّ اتخاذ قراراتههم .

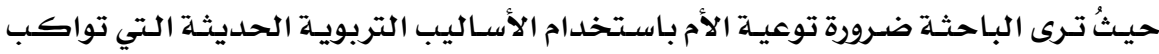

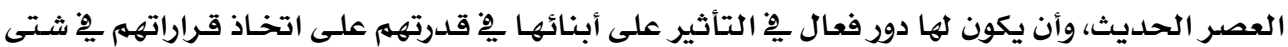

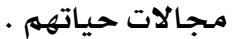
مِّ حين توجد علاقة ارتباطية موجبـة بين الأسلوب الإرشـادي التوجيهي لـلأم، واتخـاذ الأبنـاء

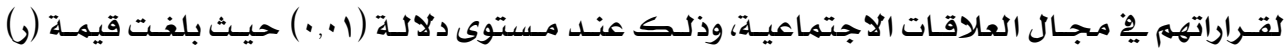

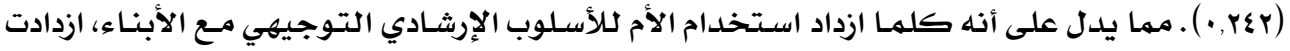

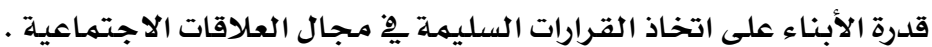
وتعزى البـاحثـة هـذه النتيجـة إلى أن الأسـلوب الإرشـادي النذي يعتمــ على النصح والتوجيـهـ

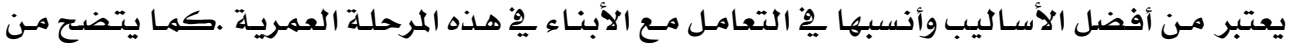
الجدول علدم وجود علاقة ارتباطيـة بـين أسـاليب المعاملــة الوالديـة لـلأم ككل ومجمـوع مجـالات اتخـاذ الأبناء لقراراتهم • وبذلك يتحقق الفرض الفرعي الثاني جزئياً .

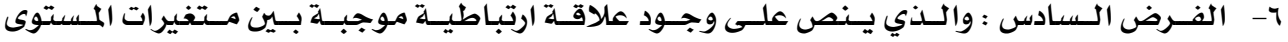
الاجتماعي والاقتصادي واتخاذ الأبناء لقراراتهم يْ المرحلة الثانوية.

جدول(19)

\section{العلاقات الارتباطية لبعض متغيرات المستوى الاجتماعي والاقتصادي وعلاقته باتخاذ القرارات للأبناء}

\begin{tabular}{|c|c|c|c|c|c|c|c|c|c|}
\hline \begin{tabular}{|c|} 
|القرارات ككل \\
\end{tabular} & 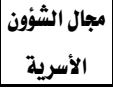 & | الاجتمالعية العلاقات & مجال & مجال & مجال & الأصدقاء & الفذاء & قضاء وقت الفراغ & المتفيرات \\
\hline . 94 & •AT & (\$) & $\therefore \cdot v r$ & 6.40 & ( & . & (\$1 & (4r & مدة الزواج \\
\hline *iltr & . Or & 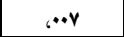 & $\therefore \wedge$ & (\$0 & 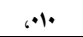 & $\therefore 0$ & .01 & $* * 10$ & مستوى تعليم الأب \\
\hline .14 & $\cdots \varepsilon$ & 1.r & (11\% & ، & 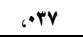 & .01 & 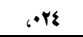 & $* *$, r $\leqslant 1$ & مستوى تعليم الأم \\
\hline 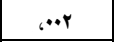 &. .14 & $* 11 \% 0$ & *.170 & .10 & . &. .4 & *iry & $\therefore \wedge 9$ & سن الأب \\
\hline$\therefore .19$ & 699 & ، 111 & $\$, 1 \& 4$ & ( & .71 & 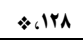 & $\cdot v 1$ & $\therefore \wedge 1$ & سن الأم \\
\hline$* *, r \cdot r$ & $* *, Y+\varepsilon$ & $* * 10 \mathrm{~V}$ & $* * 174$ & $* 1 \leqslant 9$ & $\therefore+4$ & $\dot{*} \cdot 1 \leqslant V$ & $* *$ iva & $* *$ rTI & الدخل الشهري الكلي للأسرة \\
\hline$*$ \&IET & \& & \& $1 \leqslant Y$ & $* *$, rT. & 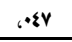 & $\% *$ IV乏 & $* .18 \cdot$ & *.1T1 & $\% \otimes \cdot$ IA & سن الأبناء \\
\hline
\end{tabular}

• \& \&الة عند مستوى 1 •, •

ثدالة عند مستوى ه •, 
يتبين من الجدول وجود علاقة ارتباطيـة موجبـة بـين المستوى التعليهـي لـلأب ولكلأم واتخـاذ

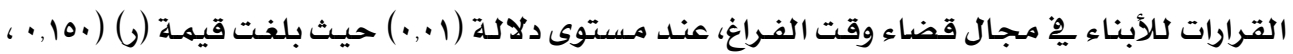

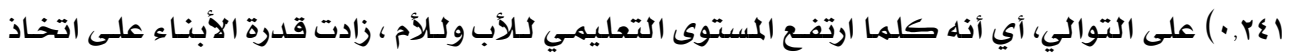

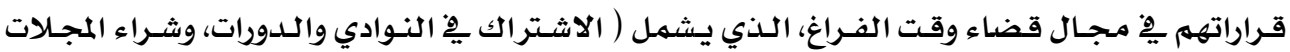

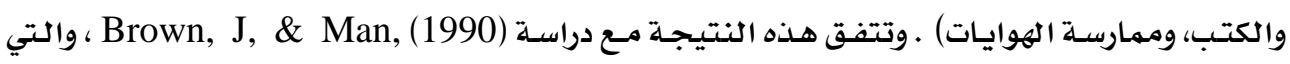

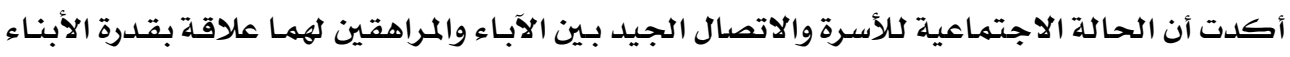

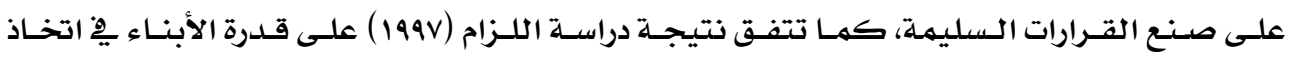

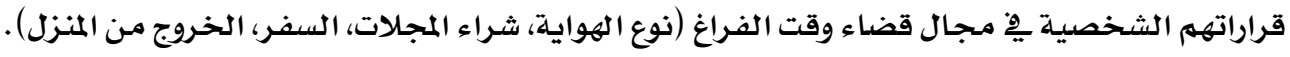

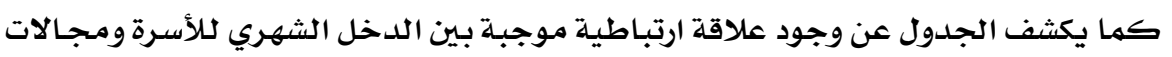

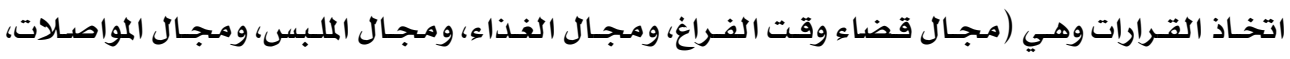

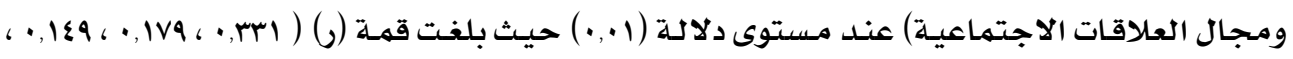

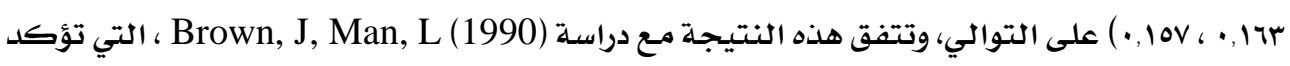

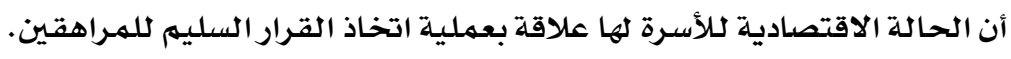

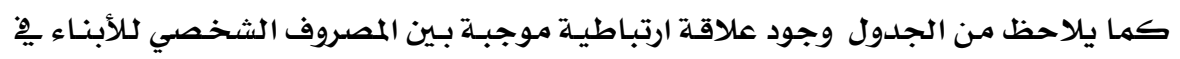

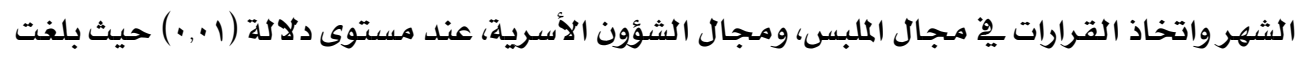

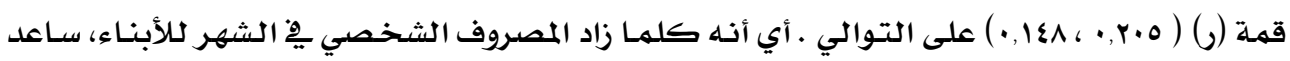

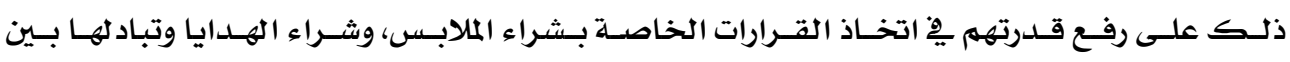

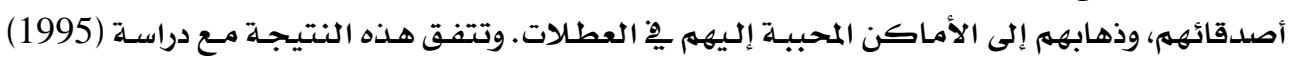

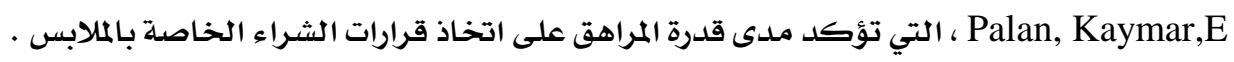

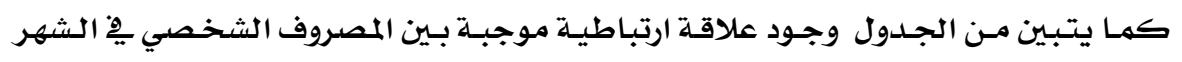

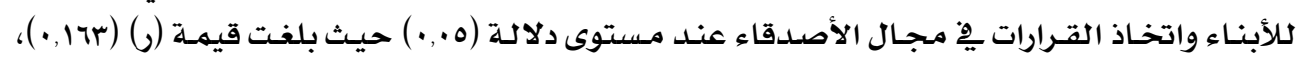

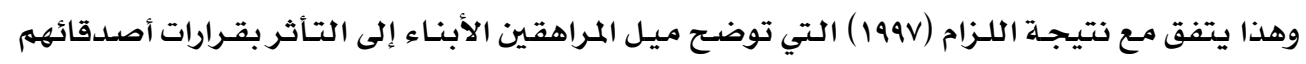

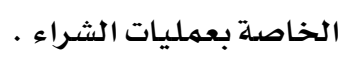

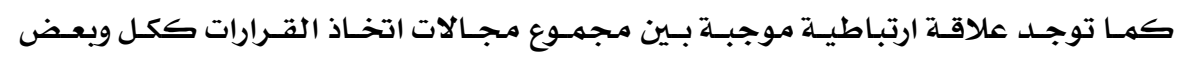

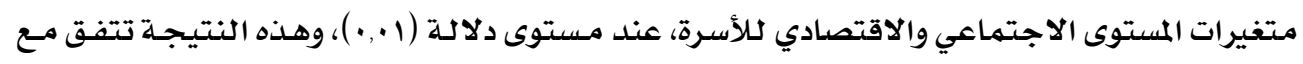

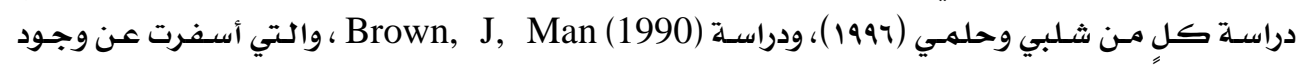

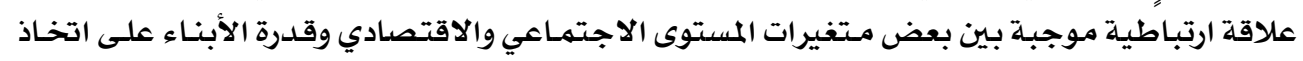

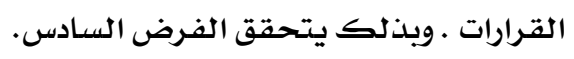

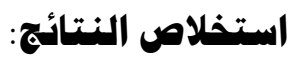

أسفرت نتائج الدراسـة الحالية عن التالي:

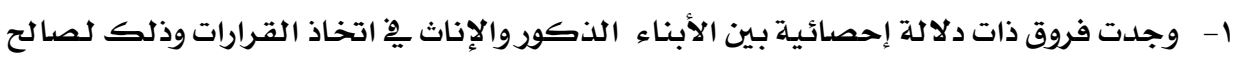

الذكور عند مستوى دلادلة (0... ). 


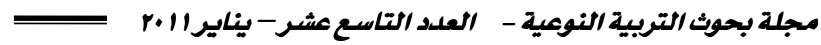

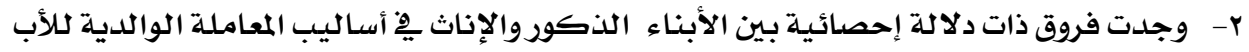

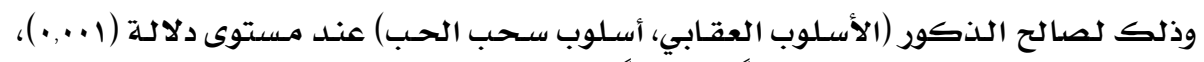

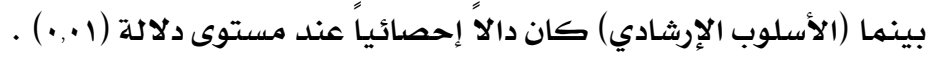

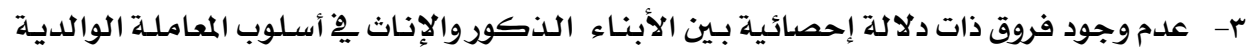

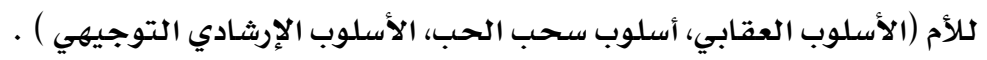

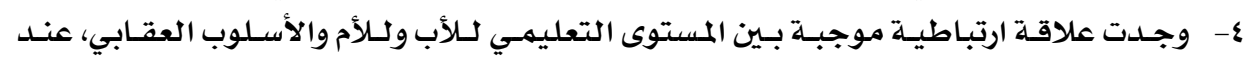

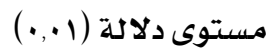

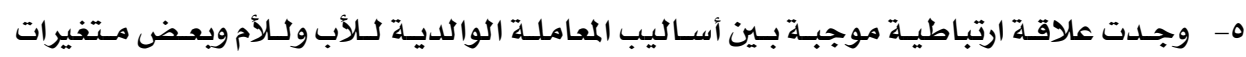

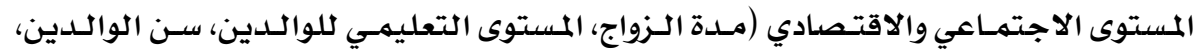

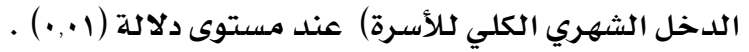

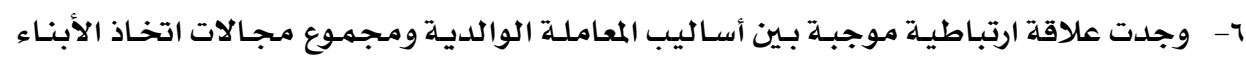
لقراراتهم عند مستوى دلالة (1 .,. ) .

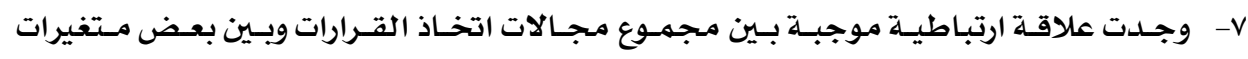
المستوى الاجتماعي والاقتصادي للأسرة.

بناءاً على نتائج الدراسـة توصي الباحثة بالتالي:

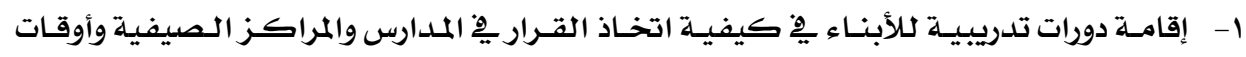
الأنشطة .

r- التأكيـد على أهميـة المراهـق ورعايتهـ كفـرد فاعل، ولـيس كتـابع وذلك مـن خـلال وسـائل الإعلام المقروءة والمسموعة والمرئية.

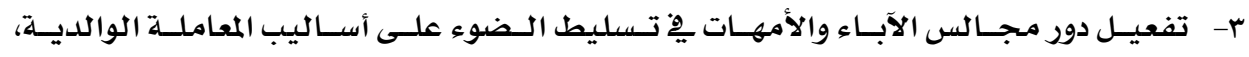
ومناقشتها بصورة أكثر موضوعيلة دورية.

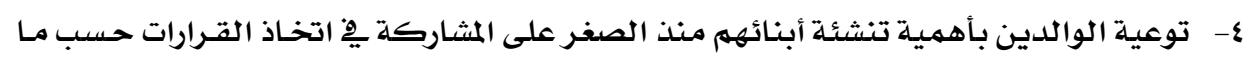

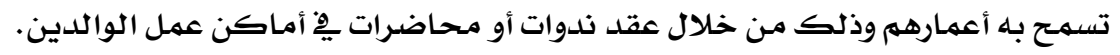

المراجم:

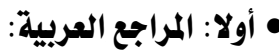

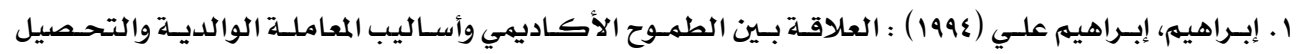

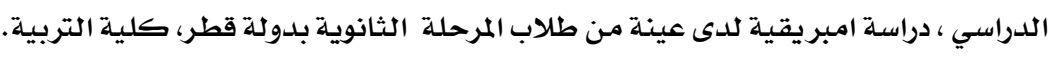

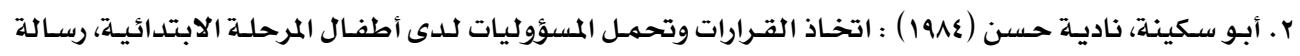

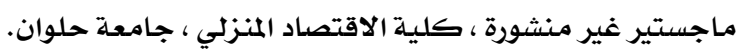

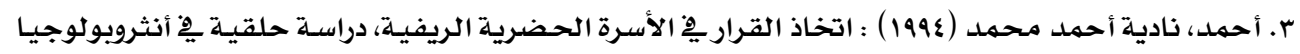
الأسرة والقرابة، رسالة دكتوراه غير منشورة، كلية الآداب ، جامعة الإسكندرية. 


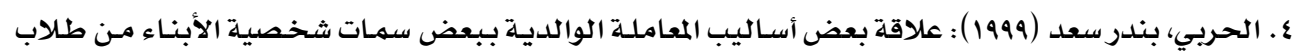

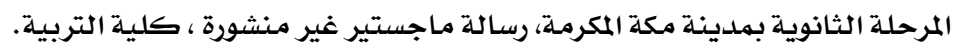

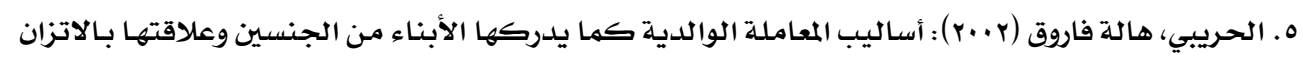

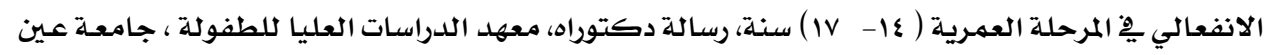

شمس.

7. الديب، أميرة عبد العزيز ( (199) ): سيكولوجية التوافق النفسي، الكويت ، مكتبة الفلاح.

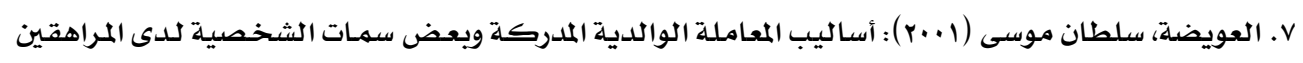

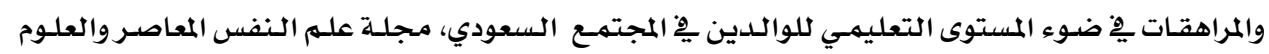

$$
\text { الإنسانية، مركز البحوث والدراسات النفسية. }
$$

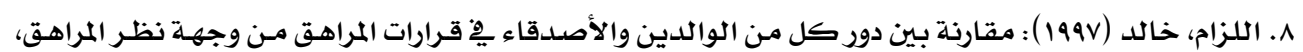

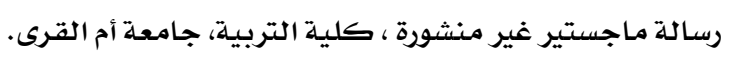

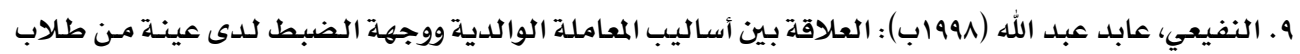

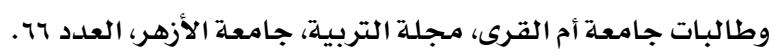

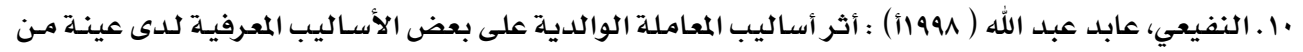

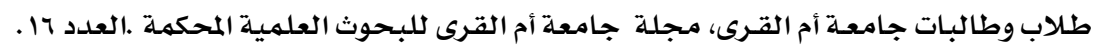

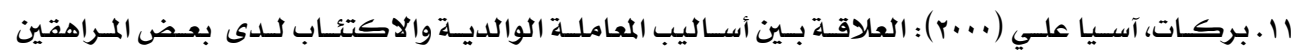

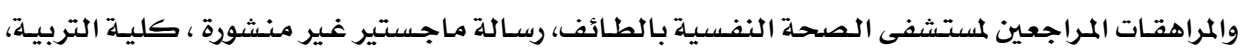

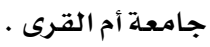

r r ا . حسيب، مجدى عبدالكريم (199V) ) سيكولوجية صنع القرار، مكتبة النهضة المصرية، القاهرة.

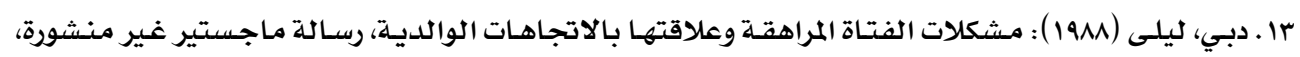

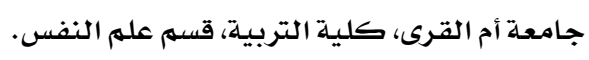

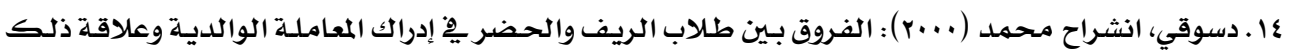

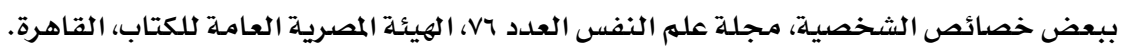

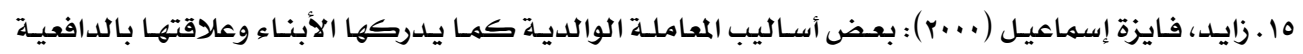

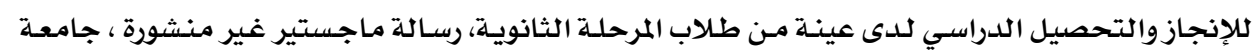

$$
\text { عين شمس، معهد الدراسات العليا للطفولة. }
$$

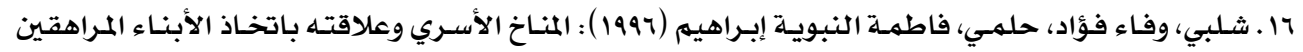

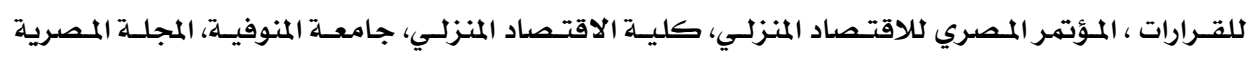
كلاقتصاد المنزبي.

V ا ـ شلبي، وفاء فؤاد (1999): إدراك الزوج لدوره يِّ المسؤوليات الأسرية وعلاقته بدافيعـة الزوجـة للإنجاز، مجلـة الاقتصاد المنزبي، جامعسة حلوان.

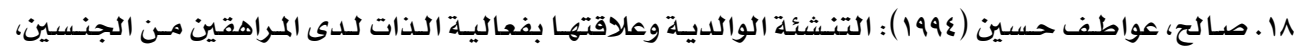
مجلة كلية التربية، جامعة المنصورة. 


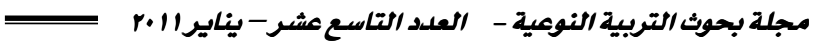

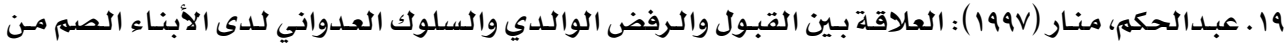

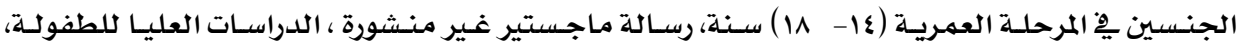
جامعة عين شمس.

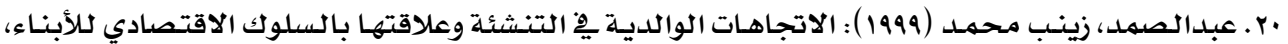
مجلة بحوث الاقتصاد المنزلي، جامعة المنوفية.

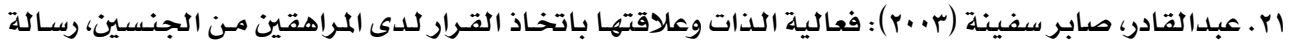
ماجستير غير منشورة ، جامعة عين شمس، معهد الدراسات العليا للطفولية.

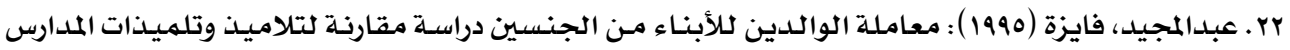
الإعدادية والثانوية ِِِ كل من الحضر والريف، دراسـات وبحوث علم النفس، دار الفكر العربي، القاهرة.

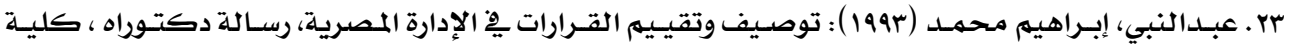
التجارة، جامعة الزقازيق.

ع r. عبيدات، ذوقان، عدس، عبدالرحمن، عبد الحق، كائد (0 . ب ) : البحث العلهي مفهومـه وأدواته وأسـاليبه، دار

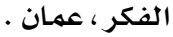

هr. عقل، مححمود عطا (r. . r) : النمو الإنسـاني (الطفولة والمراهقة)، دار الخريجي للنشر والتوزيع، الرياض .

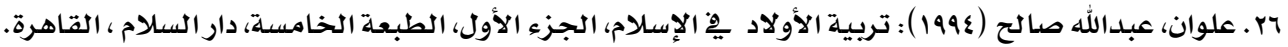

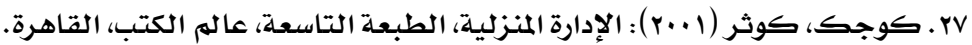

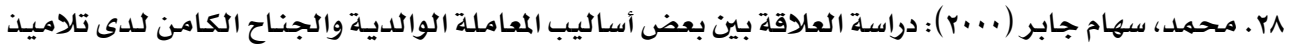
التعليه الأساسي، رسالة ماجستير غير منشورة ، معهد الدراسات العليا للطفولة ، جامعة عين شمس.

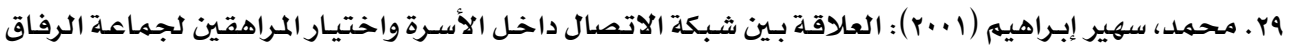
غير السوية، رسالة ماجستير غير منشورة ، كلية الآداب والعلوم العامـة، جامعة عين شمس.

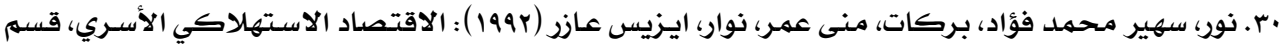
الاقتصاد المنزلي، كلية الزراعة، جامعة الإسكندريـة .

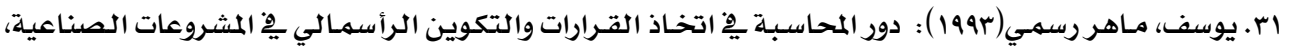
رسالة ماجستير غير منششورة ، كلية التجارة، جامعة الزقازيق.

\section{• انيا:المراجع الأجنبية:}

32-Brown , d\& mann, L (1990): The relation ship between the family structure and the variable effecting the process off design making, New York.

33-Gohn willy, sons (1994): Encyclopedia of psychology, 2nd Ed. Vol.1.

34-Palan, kaymric (1995): Family decision making as tudy of parent - Ad descent interactions in the purchase Decision making process Diss A65. Degree, B. H. Dai, A55-109, B2477.

35-Poduska, Andi (1980): Understanding psychology and dimension of adjustment, New York, McGraw - Hill. 